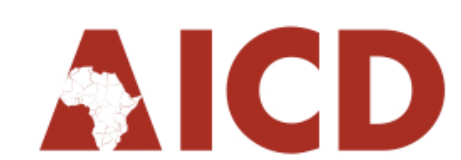

AFRICA INFRASTRUCTURE

COUNTRY DIAGNOSTIC

COUNTRY REPORT

\title{
Burkina Faso's Infrastructure: A Continental Perspective
}

Cecilia Briceño-Garmendia and Carolina Domínguez-Torres

MAY 2011

Africa's Infrastructure | A Time for Transformation 
(C) 2011 The International Bank for Reconstruction and Development / The World Bank

1818 H Street, NW

Washington, DC 20433 USA

Telephone: 202-473-1000

Internet: www.worldbank.org

E-mail: feedback@worldbank.org

All rights reserved

A publication of the World Bank.

The World Bank

1818 H Street, NW

Washington, DC 20433 USA

The findings, interpretations, and conclusions expressed herein are those of the author(s) and do not necessarily reflect the views of the Executive Directors of the International Bank for Reconstruction and Development / The World Bank or the governments they represent.

The World Bank does not guarantee the accuracy of the data included in this work. The boundaries, colors, denominations, and other information shown on any map in this work do not imply any judgment on the part of The World Bank concerning the legal status of any territory or the endorsement or acceptance of such boundaries.

\section{Rights and permissions}

The material in this publication is copyrighted. Copying and/or transmitting portions or all of this work without permission may be a violation of applicable law. The International Bank for Reconstruction and Development / The World Bank encourages dissemination of its work and will normally grant permission to reproduce portions of the work promptly.

For permission to photocopy or reprint any part of this work, please send a request with complete information to the Copyright Clearance Center Inc., 222 Rosewood Drive, Danvers, MA 01923 USA; telephone: 978-750-8400; fax: 978-750-4470; Internet: www.copyright.com.

All other queries on rights and licenses, including subsidiary rights, should be addressed to the Office of the Publisher, The World Bank, 1818 H Street, NW, Washington, DC 20433 USA; fax: 202-522-2422; e-mail: pubrights@worldbank.org. 


\section{AICD \\ AFRICA INFRASTRUCTURE COUNTRY DIAGNOSTIC}

\section{About AICD and its country reports}

This study is a product of the Africa Infrastructure Country Diagnostic (AICD), a project designed to expand the world's knowledge of physical infrastructure in Africa. The AICD provides a baseline against which future improvements in infrastructure services can be measured, making it possible to monitor the results achieved from donor support. It also offers a solid empirical foundation for prioritizing investments and designing policy reforms in Africa's infrastructure sectors.

The AICD is based on an unprecedented effort to collect detailed economic and technical data on African infrastructure. The project has produced a series of original reports on public expenditure, spending needs, and sector performance in each of the main infrastructure sectors, including energy, information and communication technologies, irrigation, transport, and water and sanitation. Africa's InfrastructureA Time for Transformation, published by the World Bank and the Agence Française de Développement (AFD) in November 2009, synthesized the most significant findings of those reports.

The focus of the AICD country reports is on benchmarking sector performance and quantifying the main financing and efficiency gaps at the country level. These reports are particularly relevant to national policy makers and development partners working on specific countries.

The AICD was commissioned by the Infrastructure Consortium for Africa following the 2005 G8 (Group of Eight) summit at Gleneagles, Scotland, which flagged the importance of scaling up donor finance for infrastructure in support of Africa's development.

The first phase of the AICD focused on 24 countries that together account for 85 percent of the gross domestic product, population, and infrastructure aid flows of Sub-Saharan Africa. The countries are: Benin, Burkina Faso, Cape Verde, Cameroon, Chad, Côte d'Ivoire, the Democratic Republic of Congo, Ethiopia, Ghana, Kenya, Lesotho, Madagascar, Malawi, Mozambique, Namibia, Niger, Nigeria, Rwanda, Senegal, South Africa, Sudan, Tanzania, Uganda, and Zambia. Under a second phase of the project, coverage was expanded to include as many of the remaining African countries as possible.

Consistent with the genesis of the project, the main focus is on the 48 countries south of the Sahara that face the most severe infrastructure challenges. Some components of the study also cover North African countries so as to provide a broader point of reference. Unless otherwise stated, therefore, the term Africa is used throughout this report as a shorthand for Sub-Saharan Africa.

The World Bank has implemented the AICD with the guidance of a steering committee that represents the African Union (AU), the New Partnership for Africa's Development (NEPAD), Africa's regional 
economic communities, the African Development Bank (AfDB), the Development Bank of Southern Africa (DBSA), and major infrastructure donors.

Financing for the AICD is provided by a multidonor trust fund to which the main contributors are the United Kingdom's Department for International Development (DFID), the Public-Private Infrastructure Advisory Facility (PPIAF), Agence Française de Développement (AFD), the European Commission, and Germany's Entwicklungsbank (KfW). A group of distinguished peer reviewers from policy-making and academic circles in Africa and beyond reviewed all of the major outputs of the study to ensure the technical quality of the work. The Sub-Saharan Africa Transport Policy Program and the Water and Sanitation Program provided technical support on data collection and analysis pertaining to their respective sectors.

The data underlying AICD's reports, as well as the reports themselves, are available to the public through an interactive Web site, www.infrastructureafrica.org, that allows users to download customized data reports and perform various simulations. Many AICD outputs will appear in the World Bank's Policy Research Working Papers series.

Inquiries concerning the availability of data sets should be directed to the volume editors at the World Bank in Washington, DC.

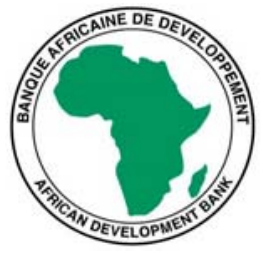

DFID

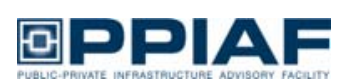

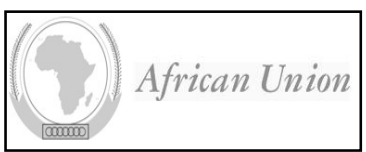
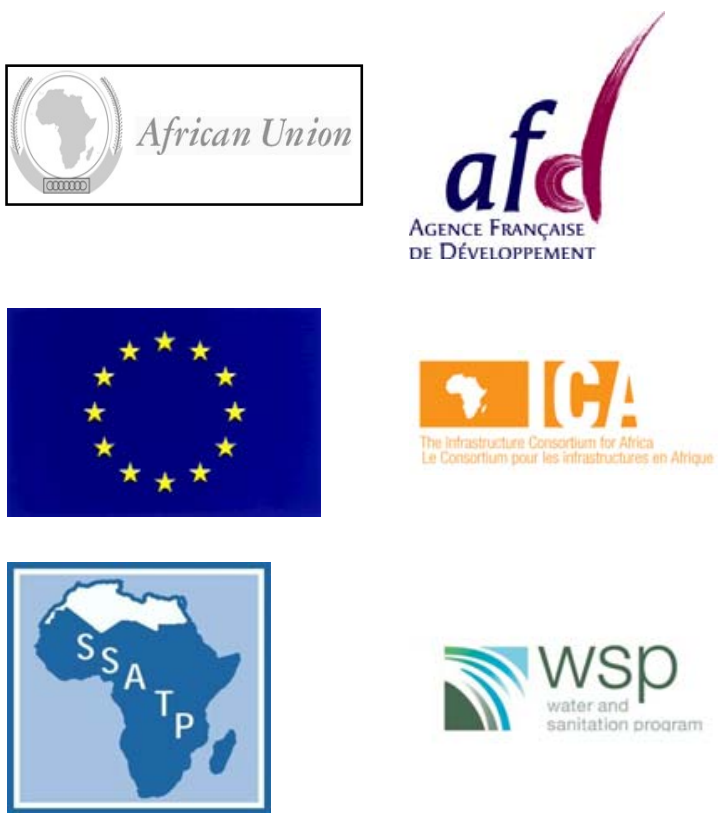
DE DÉVELOPPEMENT

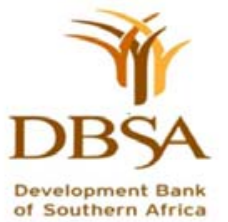

Development Bank
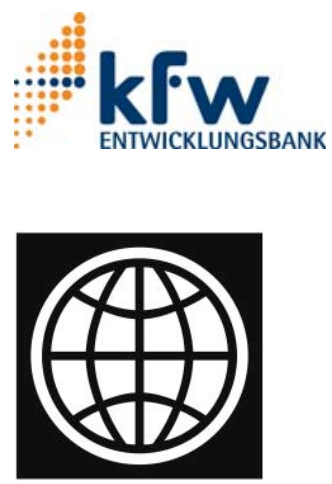


\section{Contents}

List of figures $\quad$ iii

List of tables $\quad$ iv

Acknowledgments

$\begin{array}{ll}\text { Synopsis } & 1\end{array}$

$\begin{array}{ll}\text { The continental perspective } & 1\end{array}$

$\begin{array}{ll}\text { Why infrastructure matters } & 2\end{array}$

The state of Burkina Faso's infrastructure $\quad 3$

Transport sector

Roads $\quad 14$

$\begin{array}{ll}\text { Rail } & 17\end{array}$

Air transport

Water supply and sanitation $\quad 22$

Power

Information and communication technologies 31

Financing Burkina Faso's infrastructure 35

How much more can be done within the existing resource envelope? 38

What else can be done?

$\begin{array}{ll}\text { Bibliography and references } & 46\end{array}$

\section{List of figures}

Figure 1. Infrastructure has contributed much to economic growth—but could contribute much more 2

Figure 2. Infrastructure deficits constrain firms' productivity 3

Figure 3. Burkina's population, income, topography, and natural resources 5

Figure 4. Burkina Faso's infrastructure 8

Figure 5. Burkina Faso-a hub of regional corridors 12

Figure 6. Road standards match traffic levels in Burkina Faso 15

Figure 7. Maintenance and rehabilitation needs of the main road network are underfunded 15

Figure 8. Spending requirements in Burkina Faso are the third-highest in the region vis-à-vis traffic levels 16

Figure 9. By comparison with its neighbors, Burkina Faso has room to increase its allocation of resources to roads 17

Figure 10. Evolution of SITARAIL's freight traffic over time 18

Figure 11. Evolution of seats and city pairs in Burkina Faso

Figure 12. Burkina Faso has made progress on improved water supply and sanitation 23

Figure 13. Evolution of hidden costs in Burkina's water sector 24

Figure 14. Hidden costs of selected water utilities, as percentage of the revenues 24

Figure 15. Urban and rural use of improved water and improved sanitation 25

Figure 16. Water prices in Burkina are among the highest in Africa 27

Figure 17. Prevailing tariffs are in line with operational costs; total costs should fall in the medium term 28

Figure 18. Hidden costs of power utilities in selected West African countries, as percentage of the revenues 30

Figure 19. Burkina's power costs are among the highest in Africa 31

Figure 20. Power price in Burkina are among the highest in Africa 31

Figure 21. Impressive expansion of the Internet market in Burkina Faso 32

Figure 22. Market concentration in Burkina Faso relatively low 33

Figure 23. There is still room for increased private participation 33

Figure 24. Telecommunications coverage in Burkina Faso 34 
Figure 25. Burkina Faso's infrastructure spending needs are greater than those of comparable countries 36 Figure 26. Spending allocated to address infrastructure needs 37

Figure 27. O\&M is predominantly financed by state-owned enterprises; investments by the central government 38

Figure 28. Underpricing of power in Burkina Faso relatively low but still material 39

Figure 29. Burkina Faso's consumption of infrastructure services is highly differentiated by budget 40

Figure 30. Distributional incidence of water and power subsidies 41

Figure 31. About half of households are able to afford subsistence consumption when the monthly bill is \$10 42

Figure 32. Undercollection and losses in the power and water sectors, as percentage of GDP 43

Figure 33. Burkina Faso needs to attract more private investment, especially outside the ICT sector 44

\section{List of tables}

Table 1. Achievements and challenges in Burkina Faso's infrastructure sectors 4

Table 2. Condition of the ECOWAS's regional road network, by selected member country 12

Table 3. Burkina Faso's barriers to trade are much higher than the rest of Africa's 13

Table 4. Trucking cartels and red tape are major contributors to high transport costs 13

Table 5. Burkina Faso's road indicators benchmarked against Africa's low- and middle-income countries 14

Table 6. Railway indicators for SITARAIL and selected other countries, 2005-09 average 18

Table 7. Benchmarking air transport indicators for Burkina Faso and selected other countries 20

Table 8. Benchmarking water and sanitation indicators 22

Table 9. Evolution of operational indicators associated with ONEA 23

Table 10. Evolution of operational indicators associated with ONEA 25

Table 11. Expansion of the safest water and sanitation technologies 26

Table 12. Benchmarking Burkina Faso's power indicators 29

Table 13. Evolution of hidden costs associated with SONABEL 30

Table 14. Benchmarking ICT indicators 32

Table 15. High international call charges driven both by technology and market power 35

Table 16. Illustrative investment targets for infrastructure in Burkina Faso 35

Table 17. Indicative infrastructure spending needs in Burkina Faso, 2006-15 36

Table 18. Financial flows to Burkina Faso infrastructure, average 2001-06 37

Table 19. Potential gains from greater operational efficiency 38

Table 20. Funding gaps by sector 43

Table 21. Adopting alternate strategies to meet targets might represent important savings 44

\section{Acknowledgments}

This paper draws on contributions from sector specialists from the Africa Infrastructure Country Diagnostic Team; notably, Heinrich Bofinger on air transport, Alberto Nogales on roads, Rupa Ranganathan on power, Michael Minges on information and communication technologies, Nataliya Pushak on public expenditure, and Alvaro Federico Barra on spatial analysis.

The paper is based on data collected by local consultants and benefited greatly from feedback provided by colleagues in the Burkina Faso country team; notably, Mavis Ampah (ICT), Koffi Ekouevi and Leopold Sedogo (power), Fabio Galli and Aguiratou Savadogo-Tinto (transport), and Seydou Traore and Abdoulaye Kane (water). 


\section{Synopsis}

Infrastructure contributed 1.3 percentage points to Burkina Faso's annual per capita gross domestic product (GDP) growth over the past decade, much of it due to improvements in information and communication technology (ICT). Raising the country's infrastructure endowment to that of the region's middle-income countries (MICs) could boost annual growth by more than 3 percentage points per capita. Today, Burkina Faso's infrastructure indicators look relatively good when compared with other lowincome countries (LICs) in Africa, but they remain far below the levels found in Africa's MICs.

Burkina Faso has made significant progress in developing its infrastructure in recent years. Thanks to the rapid modernization of the ICT sector, around 60 percent of the population lives within range of a global system for mobile communications (GSM) cell-phone signal. The expansion of safe water and sanitation technologies in urban areas since the late 1990s and the establishment of a system for funding road maintenance (by reducing the cost of road travel) should pay long-term dividends to the economy.

Looking ahead, the country's greatest infrastructure challenge lies in the transport sector, for maintaining existing assets and improving logistics demand, strengthening overall institutional capacity, and increasing political commitment and regional cooperation. Investment in extending road access to agricultural areas is also needed. A second need is to reduce the cost of electricity by developing the power trade and improving the operational efficiency of the national power utility. Finally, low levels of access to improved sanitation and rural water and sanitation services are holding Burkina Faso back from attaining the Millennium Development Goals (MDGs).

Addressing Burkina Faso's infrastructure deficit by bringing it up to the level of the regional leader, Mauritius, would require sustained expenditure of \$613 million per year over the next decade-two-thirds for capital investment and one-third for operations and maintenance. One-third of this relates to the achievement of the MDGs for water supply and sanitation, a quarter to improving the reliability and availability of power generation capacity, and another quarter to improving transport modes. At just over 11 percent of GDP, this level of effort would be comparable to what China has spent in recent years-a significant stretch for Burkina Faso's economy.

As of 2007, the gap between the amount needed and the amount available was $\$ 165$ million per year, or 4 percent of GDP. That gap could be cut in half by the adoption of more appropriate technologies to meet infrastructure targets in the transport and the water and sanitation sectors. Even if Burkina Faso were unable to increase infrastructure spending or otherwise close the infrastructure funding gap, simply by moving from a 10- to 18-year horizon the country could address its efficiency gap and meet the posited infrastructure targets.

\section{The continental perspective}

The Africa Infrastructure Country Diagnostic (AICD) has gathered and analyzed extensive data on infrastructure across almost all African countries, including Burkina Faso. The results have been presented in reports covering different areas of infrastructure-including ICT, irrigation, power, transport, 
and water and sanitation—and various policy areas, including investment needs, fiscal costs, and sector performance.

This report presents the key AICD findings for Burkina Faso, allowing the country's infrastructure situation to be benchmarked against that of its African peers. Two sets of African benchmarks will be used to evaluate Burkina Faso's situation: nonfragile LICs and MICs. Detailed comparisons will also be made with immediate regional neighbors in the West African Community.

Several methodological issues should be borne in mind. First, because of the cross-country nature of data collection, a time lag is inevitable. The period covered by the AICD runs from 2001 to 2006. Most technical data presented are for 2006 (or the most recent year available), while financial data are typically averaged over the available period to smooth out the effect of short-term fluctuations. Second, to make comparisons across countries, we had to standardize the indicators and analysis so that everything was done on a consistent basis. This means that some of the indicators presented here may be slightly different from those that are routinely reported and discussed at the country level.

\section{Why infrastructure matters}

In the years 1997-2007, Burkina Faso's economy grew at an average annual rate of 6 percent, which (taking population growth into account) translates to roughly 2.5 percent growth per capita during the period. About half of this improved performance can be traced to improvements in the country's infrastructure platform (Calderón, 2009), much of it in the ICT sector, which contributed 1.14 percent points alone. Meanwhile, deficient roads held growth back by at least 0.1 percent points (figure 1a).

Figure 1. Infrastructure has contributed much to economic growth-but could contribute much more
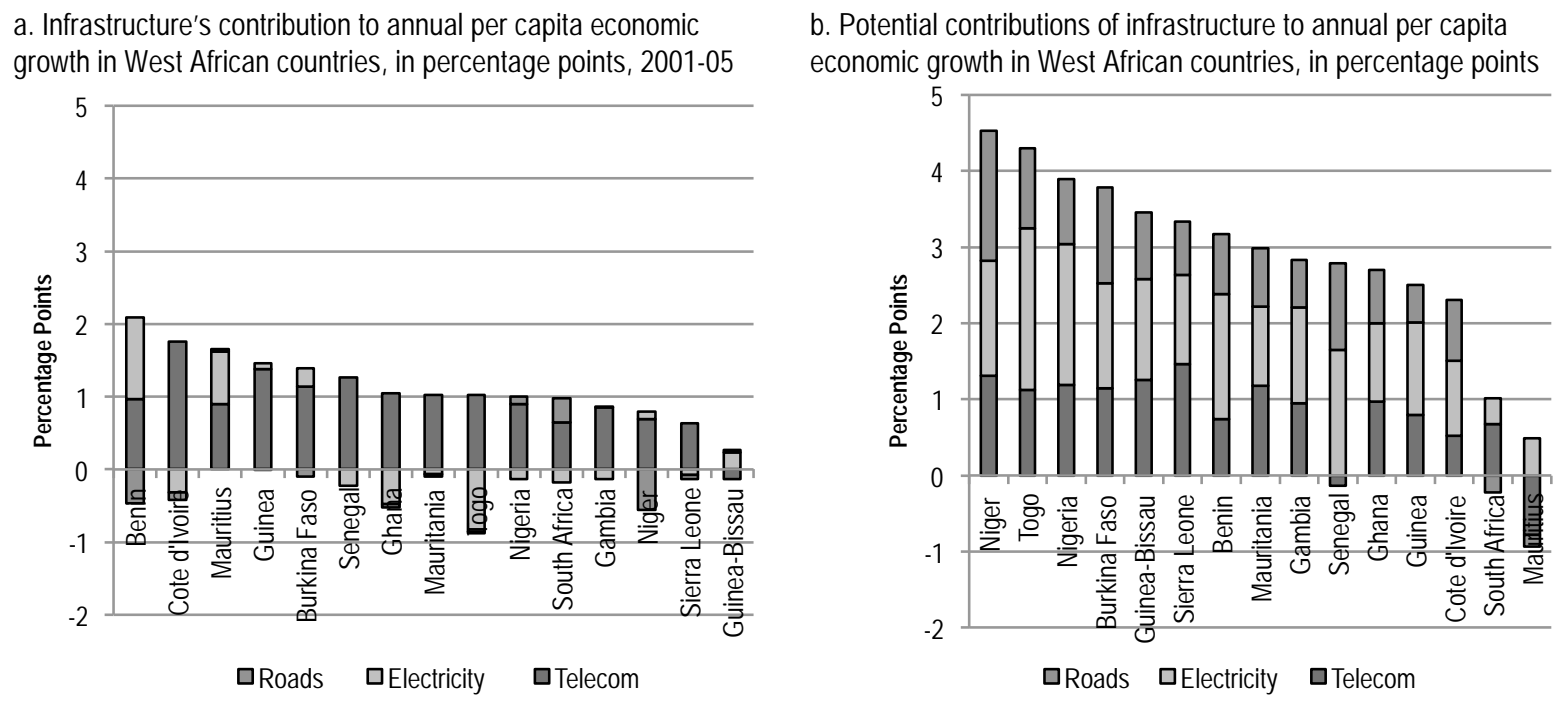

Source: Calderón 2009. 
Simulations suggest that addressing Burkina's infrastructure deficiencies —understood as improving the quantity and quality of infrastructure to the level of the African leader, Mauritius-could boost growth by 3.8 percentage points, with potential contributions coming equally from the ICT, road, and power sectors (figure $1 b$ ).

At the firm level, evidence from enterprise surveys suggests that infrastructure quantity and quality are responsible for about one-third (35 percent) of the productivity performance of Burkina Faso firms (figure 2a). "Soft" issues related to transport—such as customs clearance and transport logistics in general—weigh most heavily on firms' productivity; electricity is a distant second.

\section{Figure 2. Infrastructure deficits constrain firms' productivity}

a. Degree to which infrastructure contributes to firm's increased productivity

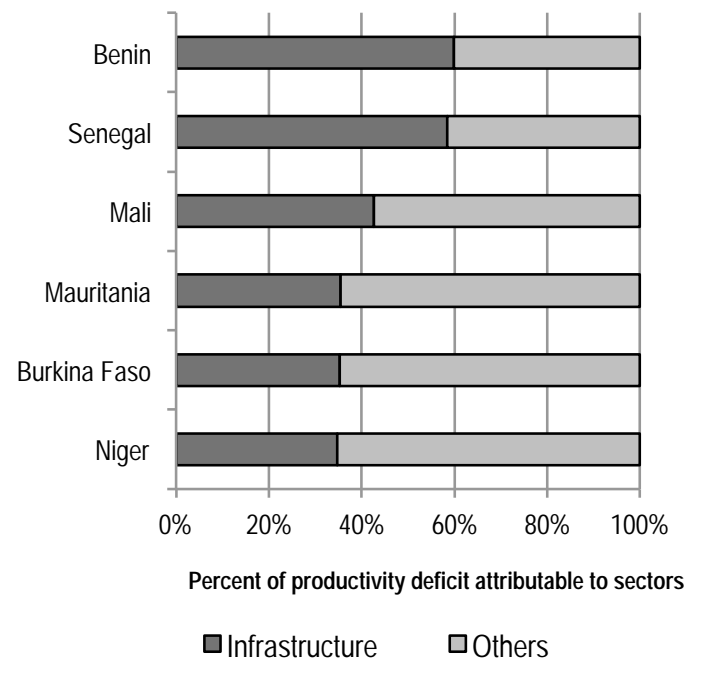

b. Degree to which infrastructure is an obstacle to firm's increased productivity, by subsector

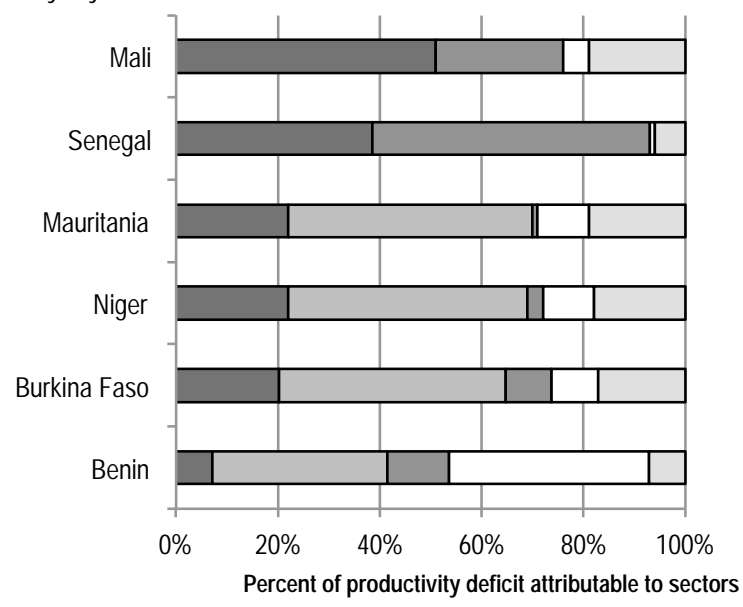

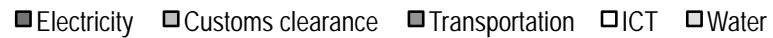

Source: Escribano, Guasch, and Pena 2009.

\section{The state of Burkina Faso's infrastructure}

The country is characterized by low population density (figure 3a) and contrasting levels of poverty and wealth across states (figure 3b). Most of Burkina's population and agricultural activity is concentrated along the Yatenga-Kadiogo-Boulgou corridor. Burkina's territory is dominated by the Volta River Basin and Niger River Delta, whose potential remain largely undeveloped (figure 3c). Mineral resources are limited and widely dispersed (figure 3d). Meanwhile, Burkina's geography poses challenges: a large share of the territory is arid and prone to drought and floods, the soil is infertile, and rivers are seasonal. Yet, agriculture constitutes 30 percent of the country's GDP. Cotton is the main export commodity and driver of economic growth, making Burkina's economy vulnerable to fluctuations in the international commodity market and to climatic and external shocks.

Burkina is also challenged by demography, with one of the fastest-growing populations in Africa. Population growth averaged 3.3 percent annually over the period 2000-08, over 30 percent above the average of other LICs, or 2.3 percent (World Bank 2009b). This rapid population increase, and the fact 
that it is concentrated in just a few geographic clusters, should be considered while provisioning for services for the next 50 years and designing the country's backbone infrastructure. Another key element, not less relevant, is Burkina's landlocked condition, which makes it highly dependent on its neighbors for transit and trade and thus highly exposed to any political instability.

It should not come as a surprise, given its geography and demography, that Burkina's infrastructure networks are anchored by the area of highest population density-Ouagadougou and its surroundingsand expand along radiuses that begin in Ouagadougou and travel to the capital cities of the neighboring countries. For the most part, the road and the ICT transmission networks have good regional connectivity and quality (figures $4 \mathrm{a}$ and $4 \mathrm{c}$ ). In contrast, the power transmission network is still composed of two disjointed lines: one connecting Boukiende to the southeast of the country and another connecting Houet to the extreme southwest of the country (figure $4 b$ ).

This report begins by reviewing the main achievements and challenges in each of Burkina Faso's major infrastructure sectors, with the key findings summarized in table 1. Thereafter, attention will turn to the problem of how to finance Burkina Faso's outstanding infrastructure needs.

Table 1. Achievements and challenges in Burkina Faso's infrastructure sectors

\begin{tabular}{|c|c|c|}
\hline & Achievements & Challenges \\
\hline Air transport & $\begin{array}{l}\text { Aircraft fleet renewed rapidly in recent years and } \\
\text { aircraft size aligned to a hub-and-spoke approach. }\end{array}$ & $\begin{array}{l}\text { Market thin and underdeveloped. } \\
\text { Very concentrated market with very little competition. } \\
\text { Safety and security remain concerns. } \\
\text { Airport facilities are in disarray. }\end{array}$ \\
\hline $\mathrm{ICT}$ & $\begin{array}{l}\text { Adoption of ICT promotion policy and sectoral } \\
\text { strategy. } \\
\text { Liberalization and deregulation of the sector. } \\
\text { Increased GSM signal coverage. } \\
\text { Low level of market power concentration. }\end{array}$ & $\begin{array}{l}\text { Prices remain high. } \\
\text { Promote competition at the international gateways to SAT- } \\
\text { 3/WASC. }\end{array}$ \\
\hline Power & $\begin{array}{l}\text { Inception of new electricity law encouraging private } \\
\text { sector participation. } \\
\text { Promotion of increased power trade and } \\
\text { interconnection to WAPP. }\end{array}$ & $\begin{array}{l}\text { Limited electrification. } \\
\text { Supply of power insufficient to satisfy demand. } \\
\text { Costs are among the highest in Africa. }\end{array}$ \\
\hline Railways & $\begin{array}{l}\text { Good labor productivity, solid traffic volumes, and } \\
\text { relatively competitive average tariffs. } \\
\text { Recovery of traffic after Côte d'lvoire crisis. } \\
\text { SITARAIL is on track to achieve its highest- ever } \\
\text { traffic volume. }\end{array}$ & $\begin{array}{l}\text { Financial distress of SITARAIL. } \\
\text { Rebalancing financial structure of the railway concession. } \\
\text { Finding alternative funding for rehabilitation backlog. }\end{array}$ \\
\hline Roads & $\begin{array}{l}\text { Good international connectivity. } \\
\text { Adequate design of road network, given the level of } \\
\text { traffic. }\end{array}$ & $\begin{array}{l}\text { Ability to provision for road maintenance. } \\
\text { Limited access from rural farms to markets. } \\
\text { High transport and transit costs due to poor logistics. } \\
\text { Ability to enforce control of axel loads particularly across } \\
\text { borders. }\end{array}$ \\
\hline $\begin{array}{l}\text { Water and } \\
\text { sanitation }\end{array}$ & $\begin{array}{l}\text { Progress in providing access to improved water } \\
\text { and sanitation, particularly in urban areas. } \\
\text { Successful private-public partnership in the water } \\
\text { utility. } \\
\text { Water utility among the most efficient in Africa. }\end{array}$ & $\begin{array}{l}\text { Sanitation MDG is off track. } \\
\text { Lack of consistent data and standardized norms for } \\
\text { monitoring progress in access. } \\
\text { Improving provision in rural areas. }\end{array}$ \\
\hline
\end{tabular}

Source: Authors' elaboration based on findings of this report.

Note: SAT-3/WASC = South Atlantic 3/West Africa Submarine Cable; GSM = global system for mobile communications; MDG = Millennium Development Goal; ICT = information and communication technology; WAPP = West African Power Pool. 
Figure 3. Burkina's population, income, topography, and natural resources

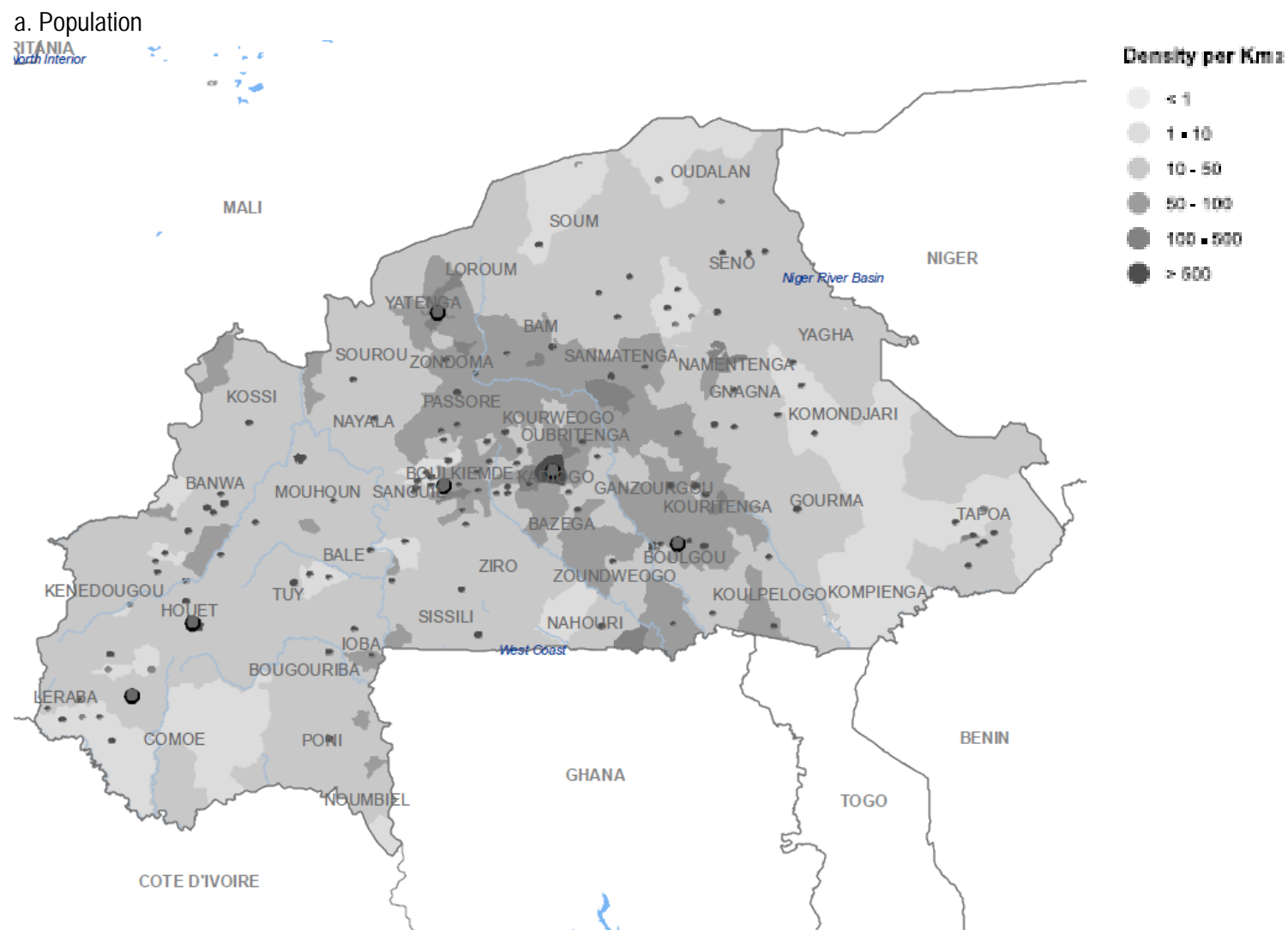




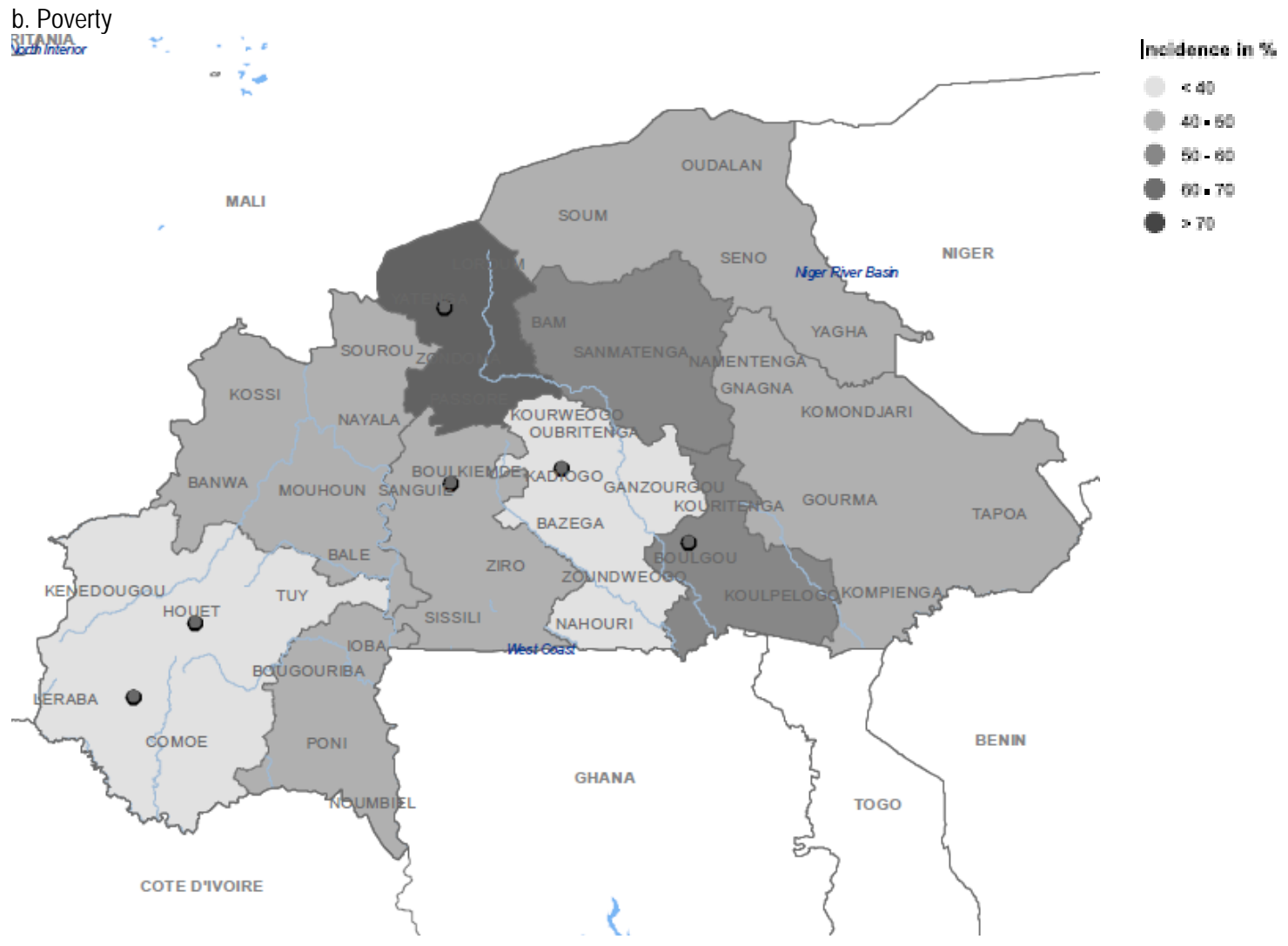

c. Topography

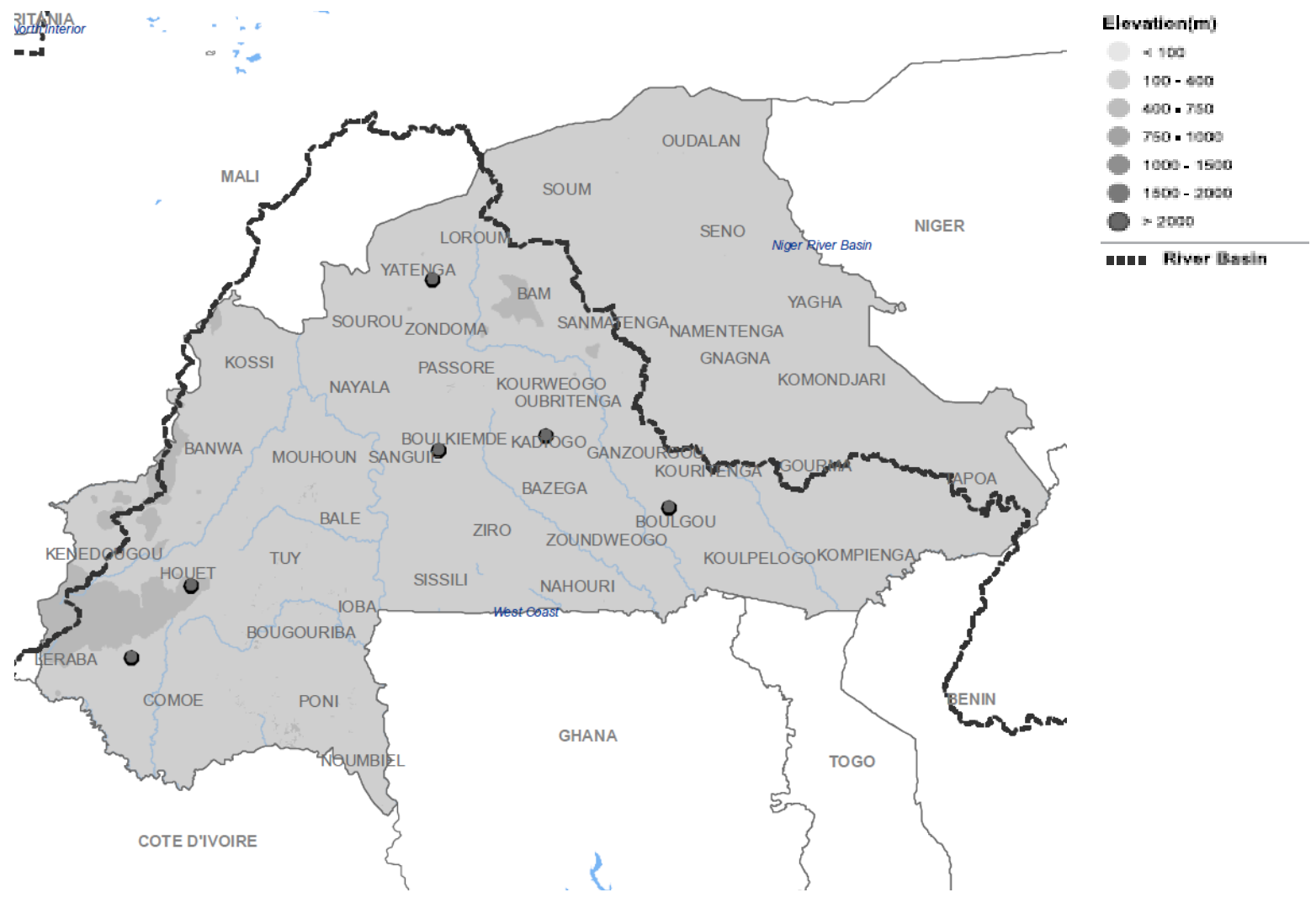




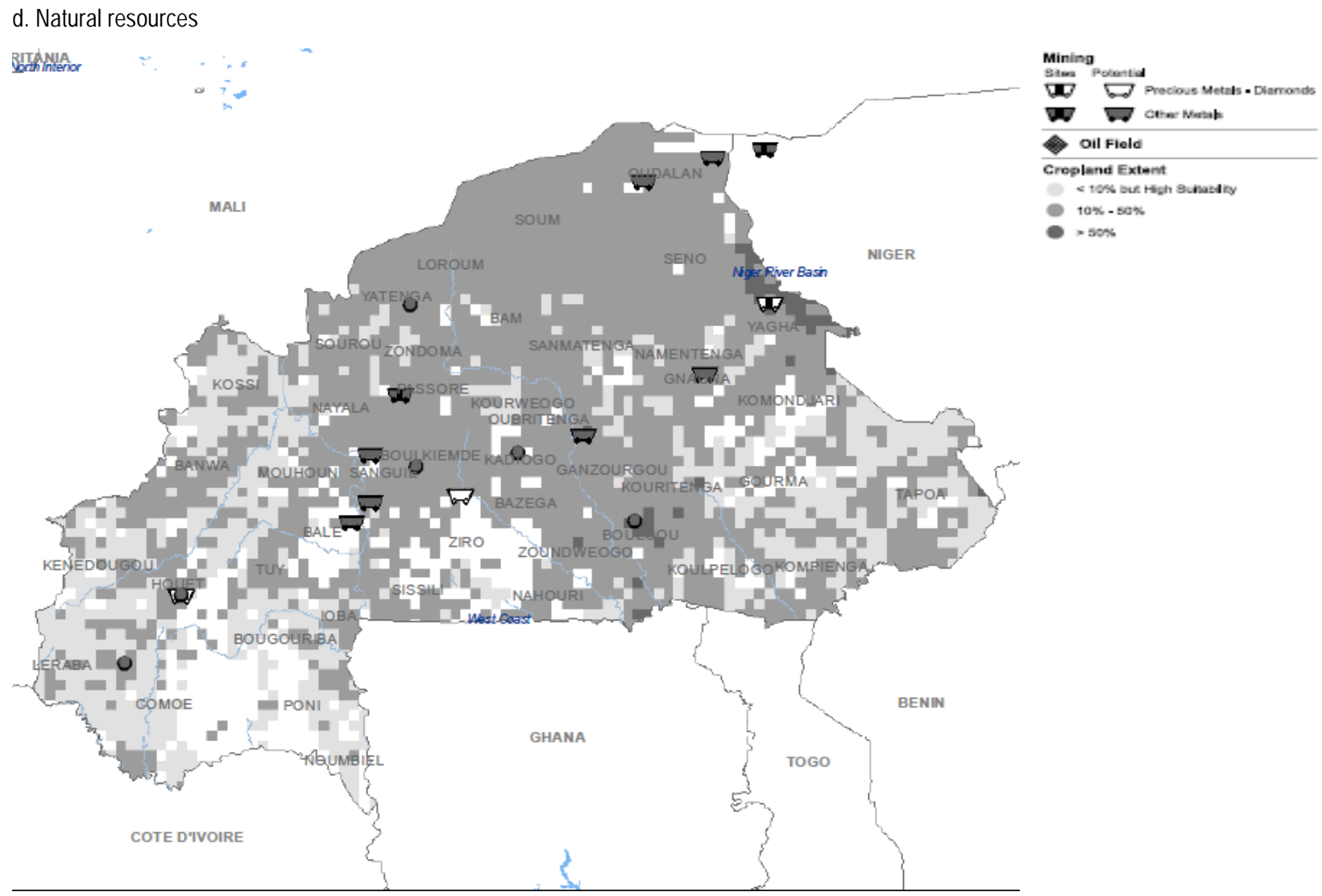

Source: AICD Interactive Infrastructure Atlas for Burkina Faso (www.infrastructureafrica.org/aicd). 
Figure 4. Burkina Faso's infrastructure

a. Roads, railways, and airports

BITHNAA

Airports (Do0 Passengers per Annum)

$$
\infty
$$

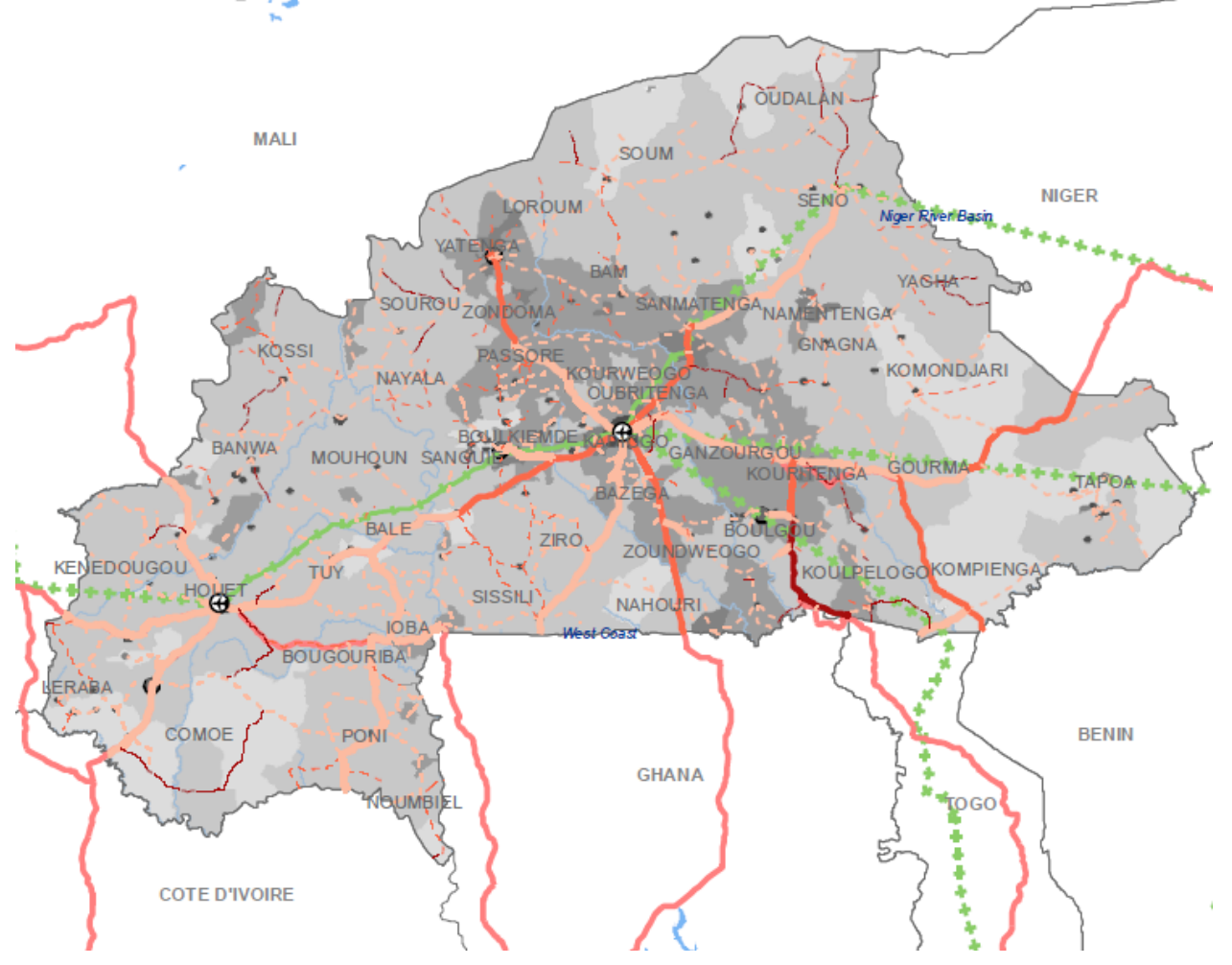

(4) $>750$ (4) 750.5000 (†) $>5000$

Ports

Direct Drect and Transipment Railroad (Mllion Trattic Unit per Annum)

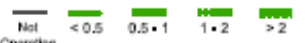
Road Traffic (Avg Anmual Daly tramc)

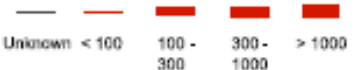
Road Type \& Condition Cose Far Pox Unienom - $=$ Pavod

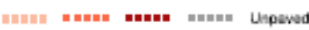




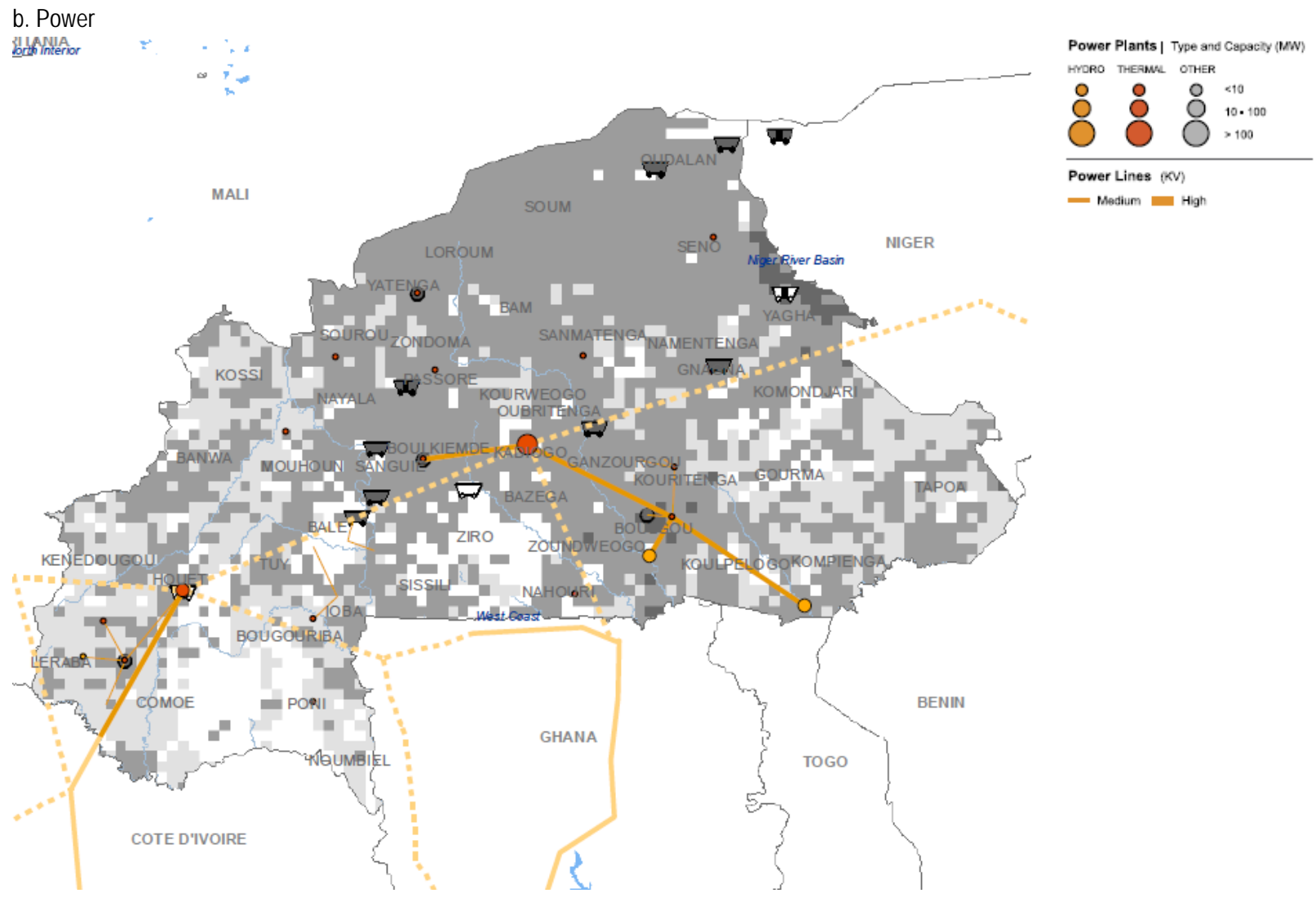




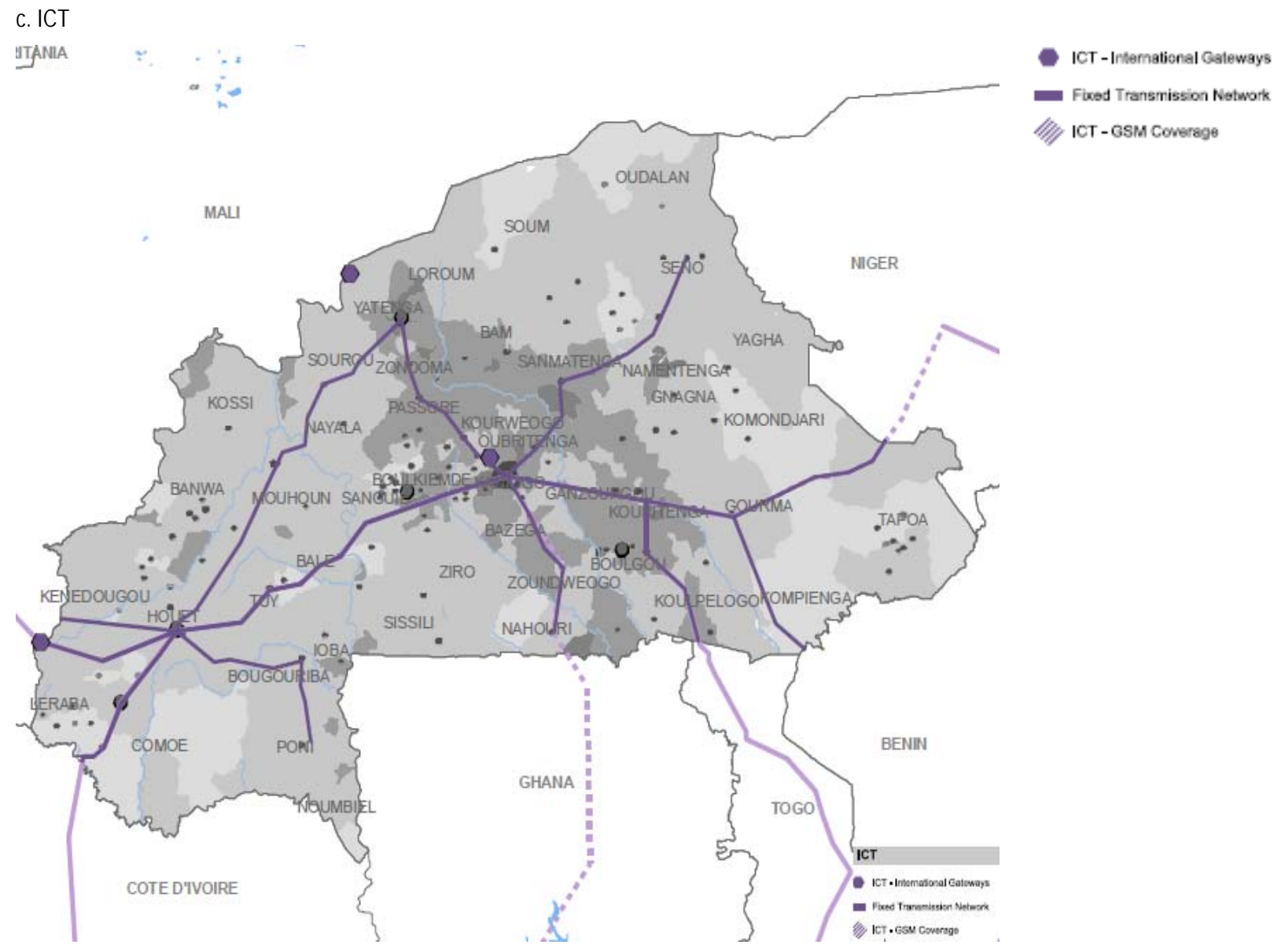




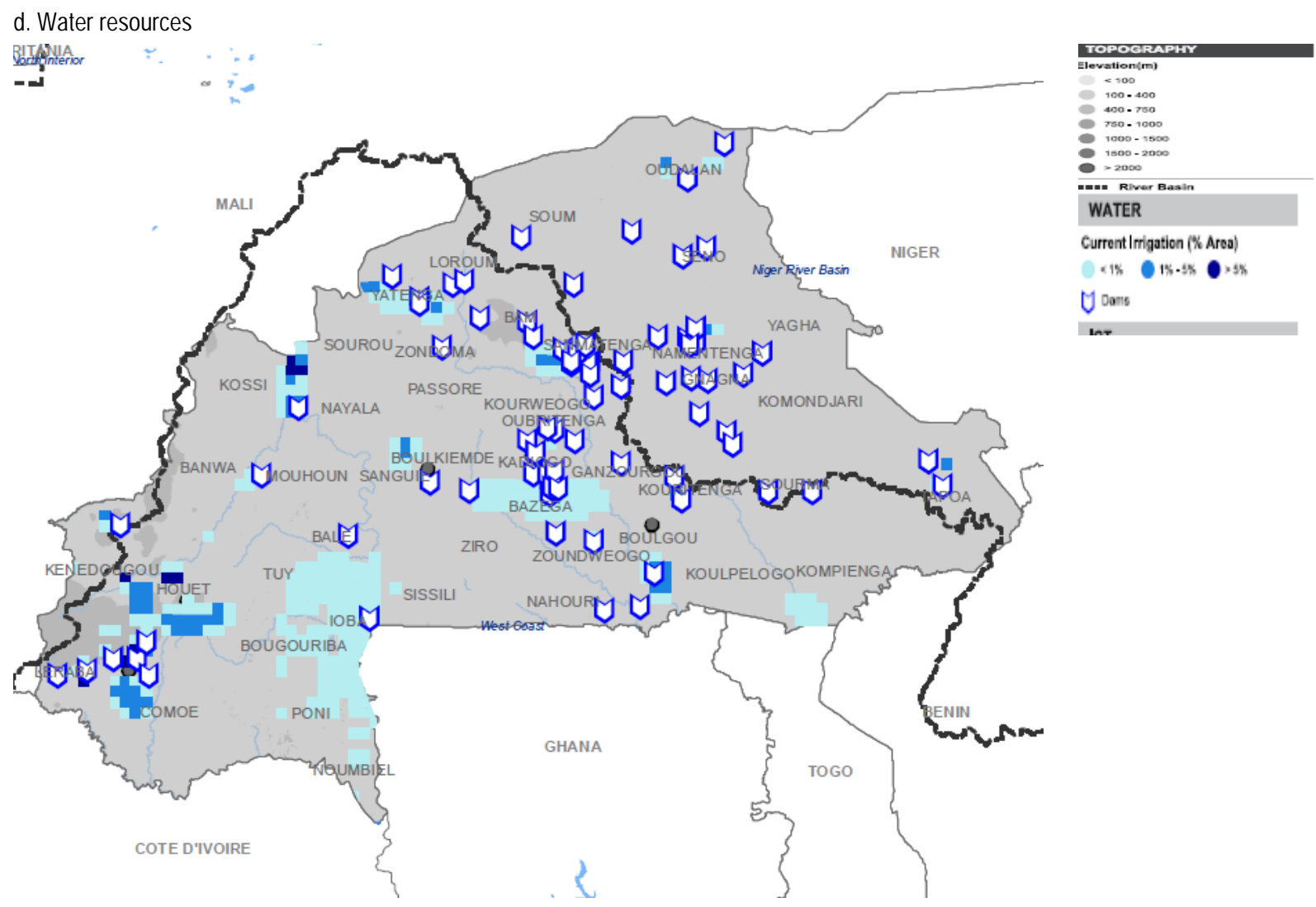

Source: AICD Interactive Infrastructure Atlas for Burkina Faso (http://www.infrastructureafrica.org/aicd).

\section{Transport sector}

Burkina Faso's landlocked nature, together with its location in West Africa, makes it a hub of regional corridors. Not only does its landlocked condition impose a markup on import and export costs, but Burkina Faso's distances from trade exit points are longer than average (about 1,000 kilometers [km] to an exit port). Consequently, transport costs are compounded by and very sensitive to any inefficiency in the transit chain, for instance, in customs administration, cross-border waiting times, and logistic costs. This same geographic location, however, positions Burkina as a natural transit hub for West Africa. Burkina serves Mali, Niger, and the northern area of Côte d'Ivoire and has the potential to benefit from its geographic position (World Bank 2007).

Burkina has made important efforts to overcome its landlocked condition and benefit from its central position. It has developed connectivity throughout four surface corridors that compete with one another and provide alternatives for Burkina's access to international ports: (i) the Abidjan Road and Railway Corridor, (ii) the Lome Corridor, (iii) the Tema Corridor, and (iv) the Cotonou Corridor (figure 5). 
Figure 5. Burkina Faso-a hub of regional corridors

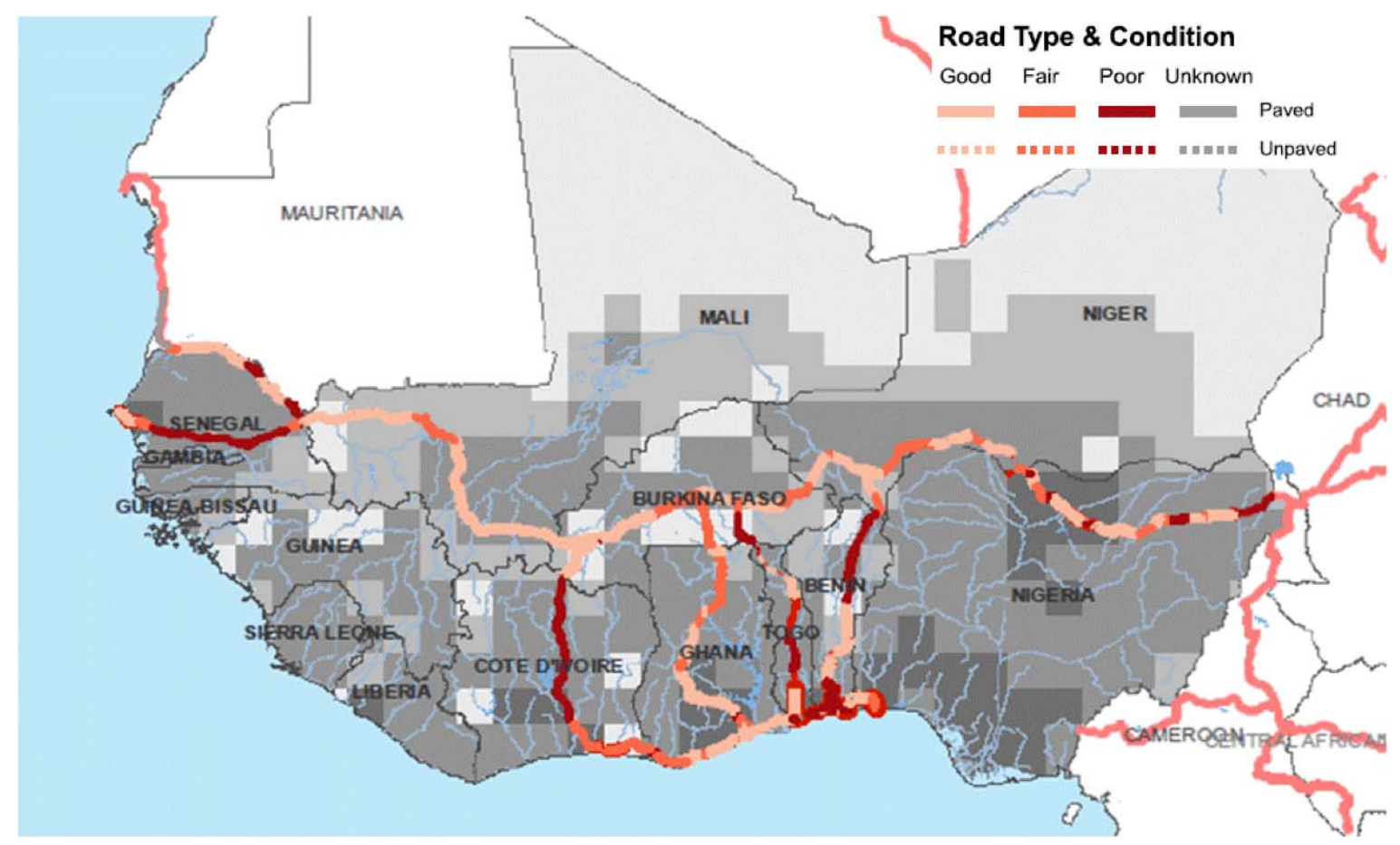

Source: AICD 2010b

Note: Road conditions as of 2006.

The country's strategic emphasis on keeping regional roads in good condition has paid off. The segments of the regional corridors running through Burkina are totally paved, and most of them-close to two-thirds - are in good condition, well above what the ECOWAS's regional corridors are on average, and significantly higher than what coastal countries reported in 2006 (table 2).

Table 2. Condition of the ECOWAS's regional road network, by selected member country

Percent of the network

\begin{tabular}{|c|c|c|c|c|c|c|c|}
\hline & \multicolumn{4}{|c|}{ Condition } & \multicolumn{3}{|c|}{ Type } \\
\hline & Good & Fair & Poor & Unknown & Paved & Unpaved & Unknown \\
\hline Burkina Faso & 58.2 & 33.6 & 8.2 & 0 & 100.0 & 0.0 & 0.0 \\
\hline Côte d'Ivoire & 16.1 & 47.1 & 35.4 & 1 & 90.3 & 9.7 & 0.0 \\
\hline Ghana & 70.3 & 23.6 & 6.1 & 0 & 100.0 & 0.0 & 0.0 \\
\hline Mali & 66.6 & 21.7 & 0.0 & 11.7 & 99.6 & 0.4 & 0.0 \\
\hline Senegal & 39.8 & 15.1 & 45.1 & 0.0 & 99.8 & 0.2 & 0.0 \\
\hline ECOWAS & 45.1 & 28.4 & 22.5 & 4.0 & 92.5 & 7.4 & 0.1 \\
\hline
\end{tabular}

Source: AICD, 2010b.

Note: ECOWAS = Economic Community of West African States. 
Despite the relatively good condition of transit roads, managing transit and easing the costs of trading across borders remain enormous challenges, and consequently, Burkina Faso faces enormous premiums on global trade. Costs to import are higher than the Sub-Saharan African average and twice as high as those faced by the Organisation for Economic Co-operation and Development (OECD) countries. Similarly, time and costs to export are among the highest-much higher than the average OECD country (table 3). Furthermore, domestic operators are forced to pay a sizeable 28 percent of the price for imports, compared to a world average of 6 percent and a Sub-Saharan African average of 10 percent (World Bank 2009a). And even as Burkina handles being the lead cotton exporter of the continent, its integration into the global economy depends on achieving cheap and reliable access to imports that, as inputs, contribute to the competitiveness of exports and production for the local market.

Table 3. Burkina Faso's barriers to trade are much higher than the rest of Africa's

\begin{tabular}{|c|c|c|c|c|c|c|c|c|c|}
\hline Indicator & $\begin{array}{c}\text { Burkina } \\
\text { Faso } \\
\end{array}$ & Niger & Mali & Cameroon & $\begin{array}{c}\text { Côte } \\
\text { d'Ivoire }\end{array}$ & Ghana & Senegal & SSA & OECD \\
\hline Documents to export (number) & 11 & 8 & 7 & 10 & 10 & 6 & 6 & 8 & 4 \\
\hline Time to export (days) & 41 & 59 & 32 & 23 & 25 & 19 & 11 & 34 & 11 \\
\hline Cost to export (\$ per container) & 2,262 & 3,545 & 2,075 & 1,250 & 1,969 & 1,013 & 1,098 & 1,942 & 1,090 \\
\hline Documents to import (number) & 11 & 10 & 10 & 11 & 9 & 7 & 5 & 9 & 5 \\
\hline Time to import (days) & 49 & 64 & 37 & 26 & 36 & 29 & 14 & 39 & 11 \\
\hline Cost to import (\$ per container) & 3,830 & 3,545 & 2,955 & 2,002 & 2,577 & 1,203 & 1,940 & 2,365 & 1,146 \\
\hline
\end{tabular}

Source: World Bank 2011.

Note: SSA = Sub-Saharan Africa; OECD = Organisation for Economic Co-operation and Development.

But what else is affecting Burkina's transport costs? Trucking cartels and red tape contribute to high transportation costs and diminished international competitiveness. The absence of competition in the trucking industry, which is operated on a cartel-type rotational basis for all operators, is the most significant contributor to high transport costs and needs to be addressed at a regional level. In fact, the western corridors in Africa are on average the most inefficient in the continent: they have the lowest implicit velocity (about $6 \mathrm{~km} /$ hour) and among the highest tariffs ( 8 cents/tonne-km) despite the relatively good quality of the roads (table 4). The enormous (implicit and explicit) costs due to regulatory and institutional failures are perhaps the underlying reason why (despite the revival of corridors with Togo, Ghana, and Benin in the wake of the Côte D'Ivoire crisis) Burkina still ranks poorly in trade across borders.

Table 4. Trucking cartels and red tape are major contributors to high transport costs

\begin{tabular}{lccccc}
\hline Corridor & Length (km) & $\begin{array}{c}\text { Roads in good } \\
\text { condition (\%) }\end{array}$ & $\begin{array}{c}\text { Trade density (\$ } \\
\text { million per km) }\end{array}$ & $\begin{array}{c}\text { Implicit velocity } \\
(\mathbf{k m} / \mathbf{h r})\end{array}$ & $\begin{array}{c}\text { Freight tariff (\$/tonne- } \\
\mathbf{k m})\end{array}$ \\
\hline Western & 2,050 & 72 & 8.2 & 6.0 & 0.08 \\
Central & 3,280 & 49 & 4.2 & 6.1 & 0.13 \\
Eastern & 2,845 & 82 & 5.7 & 27.9 & 0.07 \\
Southern & 5,000 & 100 & 11.6 & 0.05 \\
\hline
\end{tabular}

Source: AICD 2010b. 


\section{Roads}

\section{Achievements}

Burkina's 15,202 km of classified road network length seems, in general, adequately designed given the level of traffic and the connectivity it provides; it is also, for the most part, in good condition. Even if Burkina Faso's classified road density indicators look relatively low by some standards, the classified network provides basic regional, national, and international connectivity, linking Ouagadougou to international border crossings and provincial capitals in the interior (table 5).

Table 5. Burkina Faso's road indicators benchmarked against Africa's low- and middle-income countries

\begin{tabular}{|c|c|c|c|c|}
\hline & Unit & $\begin{array}{c}\text { Low- } \\
\text { income } \\
\text { countries }\end{array}$ & $\begin{array}{l}\text { Burkina } \\
\text { Faso }\end{array}$ & $\begin{array}{l}\text { Middle- } \\
\text { income } \\
\text { countries }\end{array}$ \\
\hline Total road density & $\mathrm{km} / 1,000 \mathrm{~km}^{2}$ of arable land & 132.1 & 81.5 & 318.4 \\
\hline Classified road density & $\mathrm{km} / 1,000 \mathrm{~km}^{2}$ of arable land & 88.2 & 55.6 & 278.4 \\
\hline $\begin{array}{l}\text { Rural accessibility index-household } \\
\text { survey }\end{array}$ & $\%$ of rural population within $2 \mathrm{~km}$ of all-season road & 34.1 & 25.0 & 62.7 \\
\hline GIS rural accessibility & $\%$ of rural population within $2 \mathrm{~km}$ of all-season road & 23.1 & 23.7 & 31.5 \\
\hline Paved road traffic & Average annual daily traffic & $1,341.1$ & 867.7 & $3,797.7$ \\
\hline Unpaved road traffic & Average annual daily traffic & 38.5 & 35.8 & 74.7 \\
\hline Paved classified network condition & $\%$ in good or fair condition & 86.2 & 96.1 & 82.0 \\
\hline Unpaved classified network condition & $\%$ in good or fair condition & 55.8 & 90.3 & 57.6 \\
\hline Perceived transport quality & $\%$ firms identifying roads as major business constraint & 27.6 & 55.8 & 18.2 \\
\hline Overengineering & $\%$ of main road network paved relative to low traffic & 29.6 & 25.9 & 18.4 \\
\hline Underengineering & $\%$ of main road network paved relative to high traffic & 13.5 & 1.0 & 20.0 \\
\hline
\end{tabular}

The selection of road standards matches traffic levels (figure 6), despite the fact that paved road traffic is very low when compared to the average for nonfragile LICs (table 5). Less than 1 percent of its classified road network is underengineered and only one-third is overengineered, but this is above the average for the region, at 27 percent. $^{1}$

\footnotetext{
${ }^{1}$ Here the definition of over- and underengineering is very basic. A segment of road is overengineered if it is paved and its daily traffic is below the 300 -vehicles-per-day (vpd) threshold. On the contrary a segment of a road is considered underengineered if it is not paved and its traffic is over $300 \mathrm{vpd}$.
} 
Figure 6. Road standards match traffic levels in Burkina Faso

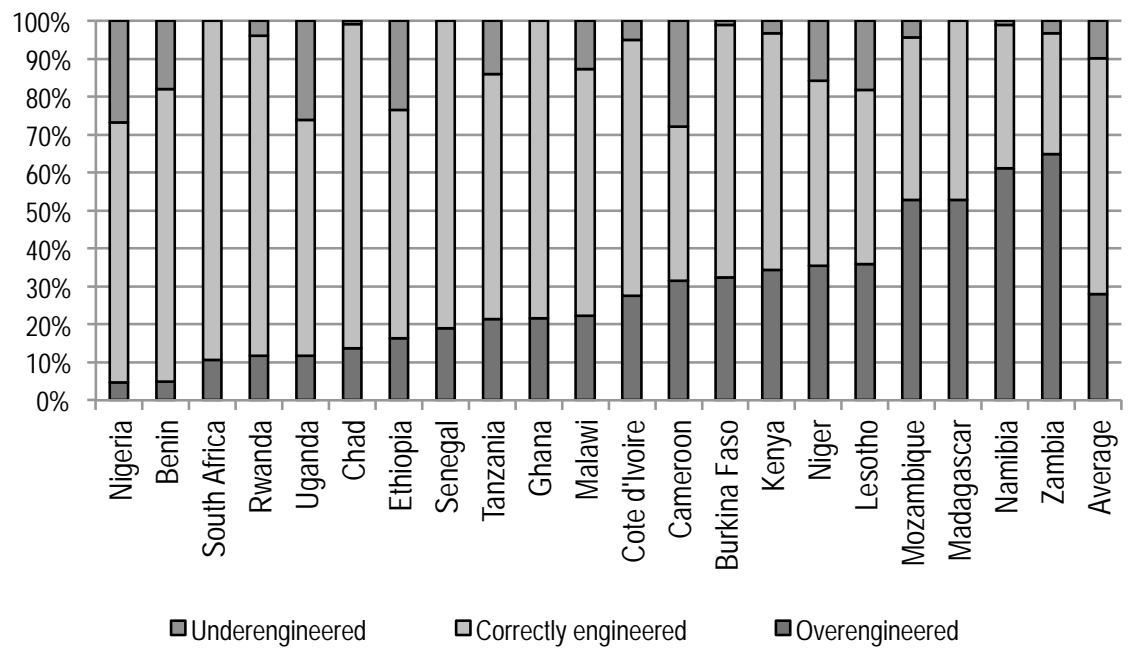

Source: Derived from AICD national database (www.infrastructureafrica.org/aicd/tools/data) using RONET.

\section{Challenges}

Burkina Faso

established a system for funding road maintenance when it adopted a secondgeneration road fund in 2007. This was an important and significant step toward effectively provisioning for road maintenance. But the level of spending is 50 percent short of the estimated requirements, if we take into consideration the size,
Figure 7. Maintenance and rehabilitation needs of the main road network are underfunded

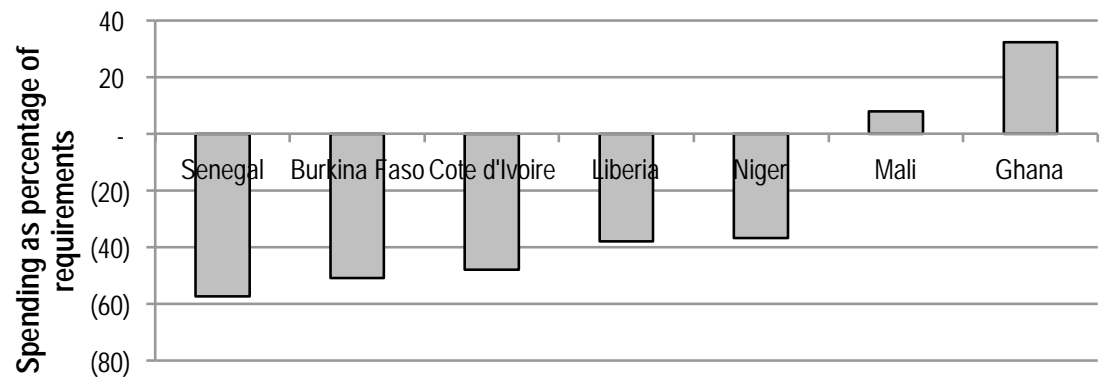
conditions, and standards of the existing networks (figure 7). Not surprisingly, the country faces a huge rehabilitation backlog that must be addressed before the trunk network can be considered to be in sustainable condition. This seems to contradict the apparent good condition of the network, which reflects the significant investment made through development assistance rather than through the enforcement of sustainable maintenance (World Bank 2007).

There are two factors that make appropriate road maintenance an uphill challenge. The first factor, exogenous to Burkina's institutions, is the disruption (due to the crisis in Côte d'Ivoire) of the historic corridor providing Burkina Faso access to the port of Abidjan, shifting traffic from the AbidjanOuagadougou Corridor to the Ouagadougou Tema, Lome, and Cotonou corridors. These corridors were not designed for the subsequent increase in traffic, which has led to an accelerated deterioration of roads and further maintenance and even rehabilitation. 
The second factor is the widespread practice of truck overloading, a factor that is endogenous to the system and reflects a lack of institutional capacity — not only in Burkina but also among its neighborsto enforce regulation and good governance practices. As the Burkinabè trucking market is regulated through the "tour de role" system, which caps cargo loads and truckers' revenues, transport providers seek to maximize their revenues by bribing freight bureaus, customs officers, and police to allow overloaded vehicles (World Bank 2009b). Needless to say, overloading exerts considerable wear and tear on the infrastructure itself. The solutions for monitoring overloading, however, are far from straightforward, particularly because part of the control should be first exercised at freight-origination points (that is, ports) rather than en route (where it is more difficult to penalize and requires regional agreements). Given the competition among ports, this approach should be coordinated between Dakar, Abidjan, Lomé, Cotonou, and Accra, and should be applied with the same rigor in each of the freightorigination points. In the current situation, a stricter application in Lomé would immediately divert traffic from landlocked countries toward Accra, especially as Ghanaian transporters are apparently those who load the most (World Bank 2007).

With all these factors put together, Burkina were to eventually fund road maintenance fully via the fuel levy collected, the levy would need to be very high—on the order of 20-30 cents per liter of gasoline consumed (figure 8) - a rate by all means unaffordable for most of the Burkinabè domestic users.

But what are the alternate sources of maintenance resources? The obvious answer is transfers from the central government, that is, increased funding from taxpayers in general. The existing level of capital spending for the road sector-at less than 1 percent of GDP - is low by regional Figure 8. Spending requirements in Burkina Faso are the thirdhighest in the region vis-à-vis traffic levels

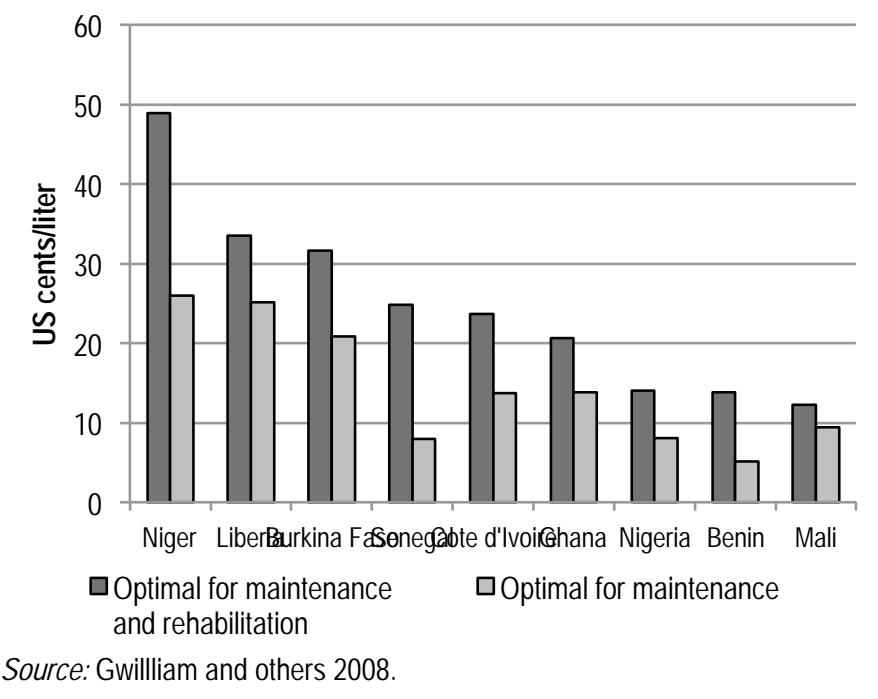
standards (figure 9). This suggests that even in the context of Burkina, which is characterized by small state revenue and a high reliance on external aid, there is some room to increase the allocation of resources to roads without creating any major unbalance in the fiscal coffer. 
Another source of funding, less obvious and certainly much more difficult to implement, puts Burkina's road spending challenge into a regional context. It calls for a hybrid system in which neighboring countries agree to not only endorse and enforce overloading regulations and facilitate the modernization of transport and logistics services in general, but also agree to share the rehabilitation and maintenance costs (as well as benefits) of the regional corridors across countries.

As discussed above, international and national connectivity-understood as the connection between the main national population centers and the neighboring capital cities-is adequate. But beyond the trunk network, accessibility falls off, particularly in rural areas. Less than one-fourth of Burkina Faso's population lives within $2 \mathrm{~km}$ of an all-weather roadperhaps comparable to the average LIC in Africa but well below the level found in Sub-Saharan MICs (table 5). The clustering of Burkina Faso's population in the middle of the country makes it comparatively demanding to achieve significant increases in rural accessibility by improving the quality of the existing rural network, in particular in the northeast areas of the country.

When making the necessary improvements, it is important to ensure that road investments are spatially synchronized with other interventions aimed at raising agricultural productivity. The need to provide a basic level of connectivity in the northeast of the country should also be taken into account. Road density is one of the main determinants of the cash income from agricultural sales in Burkina, along with agriculture yield, high-value crops, and direct selling to markets (World Bank 2009b).

\section{Rail}

\section{Achievements}

Burkina Faso has a transnational railway line jointly owned by Côte d'Ivoire. SITARAIL was established in 1995 as a result of the merger of the national railways of the two countries. The rail line links the port of Abidjan to Ouagadougou and is a key conduit for bulk freight from and into the landlocked hinterland of Burkina Faso. The line was the first in Sub-Saharan Africa to be awarded as a concession to the private sector. Benchmarking with other African rail lines indicates that SITARAIL is one of the strongest performers on a wide range of operational indicators, including labor productivity, traffic volumes, and average tariffs (table 6). Strong traffic growth took place during the first five years of the concession, from 1995 to 2000, when the volume of freight almost tripled from 450 million to 700 million tonne-km. But due to political disruptions that started in 2002, SITARAIL's traffic volumes dropped dramatically. After the crisis, SITARAIL recovered progressively, and from 2006 onwards it once again reached, and 
then exceeded, the peak volumes of the early 2000s (figure 10). As of 2010 SITARAIL was on track to achieve its highest-ever traffic volume of more than 900 million tonne-km.

Table 6. Railway indicators for SITARAIL and selected other countries, 2005-09 average

\begin{tabular}{|c|c|c|c|c|}
\hline & SITARAIL & TRANSRAIL & CAMRAIL & MADARAIL \\
\hline & $\begin{array}{l}\text { Côte d'Ivoire } \\
\text { Burkina Faso }\end{array}$ & $\begin{array}{c}\text { Senegal } \\
\text { Mali }\end{array}$ & Cameroon & (Madagascar) \\
\hline Concessioned (1)/ state run (0) & 1 & 1 & 1 & 1 \\
\hline Freight traffic volume (million tonne-km) & 794 & 393 & 1,061 & 113 \\
\hline Passenger traffic volume (million passenger-km) & 210 & 91 & 377 & 3 \\
\hline Total traffic volume (million TU)* & 878 & 429 & 1,212 & 114 \\
\hline \multicolumn{5}{|l|}{ Efficiency } \\
\hline Staff: 1,000 TU per staff & 558 & 247 & 547 & 118 \\
\hline Derailments/million TU & 0.01 & 0.45 & 0.15 & 2.31 \\
\hline Mainline locomotive breakdowns per $100,000 \mathrm{~km}$ & 6 & 15 & 9 & 6 \\
\hline \multicolumn{5}{|l|}{ Tariffs } \\
\hline Average unit tariff, freight, cents/tonne-km & 6.3 & 7.0 & 8.1 & 6.0 \\
\hline
\end{tabular}

Source: World Bank 2010; Bullock 2009. Derived from AICD rail operator database (www.infrastructureafrica.org/aicd/tools/data). $-=$ Not available.

Note: * With 2.5 passenger-km equivalent to $1 \mathrm{TU}, 1$ tonne-km equivalent to $1 \mathrm{TU}$.

$\mathrm{TU}=$ traffic unit.

Figure 10. Evolution of SITARAIL's freight traffic over time

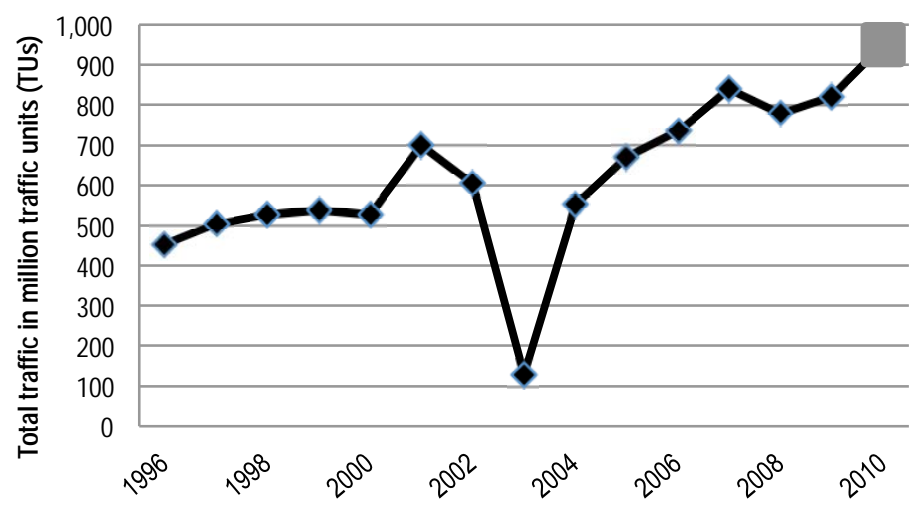

Source: AICD 2006; WB/AfDB 2009.

Note: $\mathbf{X}=$ Projection for 2010 .

\section{Challenges}

In spite of its impressive operational performance, SITARAIL is in financial distress due to the accumulation of losses made during the crisis period and the related financial liabilities it owes to stateowned asset-holding companies. SITARAIL's total financial war-related losses are equivalent to $\$ 38.6$ million. They include: (i) physical damage ( $\$ 5.7$ million), (ii) loss of income to employees (\$9.7 million), (iii) nonpayment of state-owned asset-holding companies' debt ( $\$ 8.6$ million), (iv) concession fee 
payments ( $\$ 1.1$ million), and (v) loss of revenues (\$13.5 million). Consequently, SITARAIL's future depends on the ability of its public and private partners to revise the current concession contract to restore the company's long-term financial viability.

SITARAIL's is an affermage/lease type of public-private partnership (PPP). But since the beginning of the concession, this arrangement has not generated enough revenues to allow both the payment of the state-owned asset-holding companies and the financing of rehabilitation of the railway infrastructure and rolling stock. As a result, only half of the planned five-year investment program of \$12.4 million has been delivered. This situation has been widespread across Sub-Saharan African rail concessions. Due to the relatively low volume of freight traffic as well as competition from the road sector, it is rarely possible for rail networks to earn sufficient revenue to finance track rehabilitation. In the case of SITARAIL, it is likely that the original forecasts made at the time of the award of the concession overestimated the likely freight traffic flows and underestimated the extent of the investment needed.

For this reason, SITARAIL is seeking ways to modify its PPP agreement a.l $\mathrm{g}$ the same lines as those of the Camrail (Cameroon) and Madarail (Madagascar) concessions, whereby both its host governments would finance the long-term infrastructure investments while the concessionaire would remain in charge of the maintenance of the track infrastructure and the financing and maintenance of the freight rolling stock. In addition, SITARAIL is seeking to obtain a payment of $\$ 38.6$ million in war-related damages from both host governments.

Investment needs for the railway network over the next 10 years have been estimated at $\$ 240$ million, of which $\$ 100$ million for freight rolling stock would be covered by SITARAIL, $\$ 60$ million for infrastructure rehabilitation and passenger rolling stock by Burkina Faso, and $\$ 80$ million for infrastructure rehabilitation and passenger rolling stock by Côte d'Ivoire. This is roughly three times the revenue of the concession in 2009 and can therefore only be met by public finance.

\section{Air transport}

\section{Achievements}

Burkina Faso is a minor player in air transportation in West Africa; it has less than 0.5 million seats per year across all traffic categories (table 7). The country has two international airports (Ouagadougou and Bobo Dioulasso) but strongly concentrated freight and passenger international traffic. The airport of Ouagadougou accounts for 95-98 percent of total traffic.

Well-developed road-rail connectivity has put Burkina logistically close-by way of surface routesto European markets (two weeks for operators who are able to control the chain), imperfectly (but surely) overcoming the hurdles imposed by a poorly developed air transportation market. ${ }^{2}$

\footnotetext{
${ }^{2}$ This is a real comparative advantage in relation to East or southern African countries, which can only export fresh produce by air (World Bank 2007).
} 
BURKINA FASO’s INFRASTRUCTURE: A CONTINENTAL PERSPECTIVE

Table 7. Benchmarking air transport indicators for Burkina Faso and selected other countries

\begin{tabular}{|c|c|c|c|c|c|c|}
\hline Country & $\begin{array}{c}\text { Burkina } \\
\text { Faso }\end{array}$ & $\begin{array}{c}\text { Côte } \\
\text { d'Ivoire }\end{array}$ & Ghana & Mali & Nigeria & Senegal \\
\hline \multicolumn{7}{|l|}{ Traffic (2007) } \\
\hline Domestic seats ('000 seats per year) & 20.3 & n.a. & 144.2 & n.a. & $1,199.6$ & 130.0 \\
\hline Seats for international travel within Africa ('000 seats per year) & 244.7 & 851.0 & 909,8 & 564.5 & $1,373.8$ & $1,260.0$ \\
\hline Seats for intercontinental travel ('000 seats per year) & 147.1 & 297.1 & 832.1 & 165.1 & $2,437.7$ & $1,230.0$ \\
\hline Seats available per capita & 0.03 & 0.06 & 0.08 & 0.06 & 0.09 & 0.23 \\
\hline Herfindahl-Hirschmann Index-air transport market (\%) & 22.89 & 9.75 & 6.28 & 11.75 & 11.28 & 11.64 \\
\hline \multicolumn{7}{|l|}{ Quality } \\
\hline Percent of seat-km in newer aircraft & 93.4 & 90.9 & 96.8 & 95.6 & 71.42 & \\
\hline Percent of carriers passing IATA/IOSA audit & 0 & 0 & 0 & 0 & 28.6 & 50.0 \\
\hline FAA/IASA audit status & No audit & Fail & Fail & No Audit & No audit & $\begin{array}{l}\text { Audit } \\
\text { (as of } \\
2007 \text { ) }\end{array}$ \\
\hline
\end{tabular}

Source: Bofinger 2009. Derived from the AICD national database (www.infrastructureafrica.org/aicd/tools/data).

Note: Herfindhal-Hirschmann Index $(\mathrm{HHI})$ is a commonly accepted measure of market concentration. It is calculated by squaring the market share of each firm competing in the market and then summing the resulting numbers. A HHI of 100 indicates the market is a monopoly, while lower the $\mathrm{HHI}$, the more diluted the market power exerted by one company/agent.

All data as of 2007 are based on estimations and computations of scheduled advertised seats, as published by the Seabury Aviation Data Group. This captures 98 percent of worldwide traffic, but a high percentage of African traffic is not captured by these data.

FAA = U.S. Federal Aviation Administration; IASA = International Aviation Safety Assessment; IATA = International Air Transport Association; IOSA = IATA International Safety Audit.

n.a. $=$ Not applicable.

Across the region, there has been a tendency for aircraft fleets to be renewed and scaled down in size to facilitate the consolidation of routes toward a hub-and spoke-system. The aircraft fleet serving Burkina Faso has been renewed rapidly in recent years, with the share of recently manufactured aircraft rising from 73 percent in 2004 to 93 percent in 2007, positioning Burkina Faso in the average range for the region (table 7).

Burkina Faso has a very active airline. Air Burkina was found in 1960s and later became part of Air Afrique. When Air Afrique collapsed in 2001, the Government of Burkina Faso privatized Air Burkina. The airline is now partially owned by the Aga Khan fund. Air Burkina passed IATA safety audit, is allowed to serve Europe, and flies both to Paris Orly and Marseille. Regular African destinations include Benin, Code d'Ivoire, Gabon, Ghana, Mali, Niger, Senegal, and Togo; and works in code share with Air Mali.

\section{Challenges}

The domestic market is barely developed and therefore very thin. In terms of seats per capita-with only one domestic route available as of 2007 and served by a single carrier-Burkina has the second-smallest domestic market in Sub-Saharan Africa, after Mali and Côte d'Ivoire. Furthermore, air transport activity is stagnant and likely affected by the collapse of regional carriers in the early 2000s (figure 11). 
The international market is among the most concentrated (that is, least competitive) in the region, with a Herfindahl-Hirschmann Index (HHI) of 23 percent (table 7). Not surprisingly, only Air France provides regular links to Europe and the bulk of Burkina's air transport market is international, though intra-African flights are double the number of intercontinental flights.

\section{Figure 11. Evolution of seats and city pairs in Burkina Faso}

a. Seats

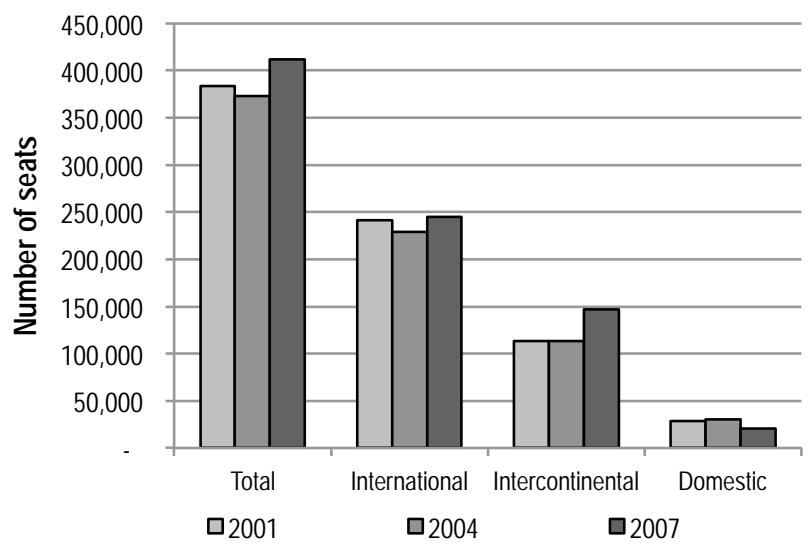

b. City pairs

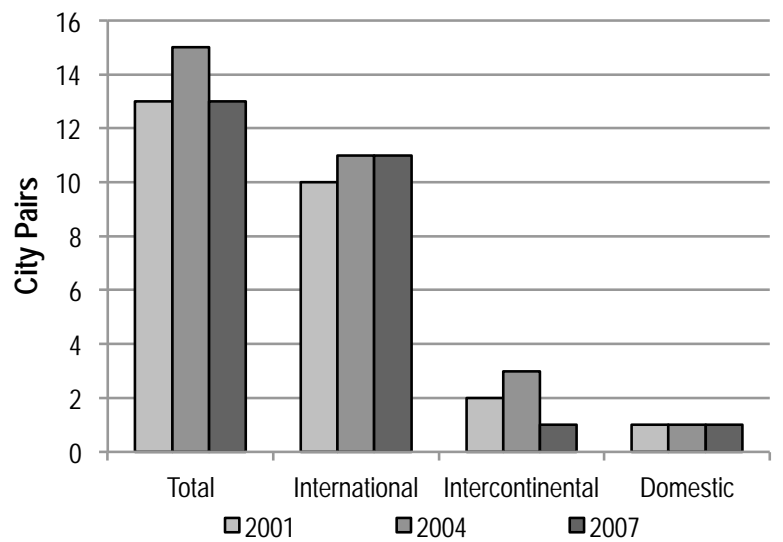

Source: Bofinger 2009. Derived from AICD national database (www.infrastructureafrica.org/aicd/tools/data).

Note: As reported to international reservation systems. Intercontinental flights excludes flights between Nigeria and South Africa.

In common with many other African countries, Burkina continues to face significant safety and security issues in air transport. Burkina Faso has not undertaken the U.S. Federal Aviation Administration/International Aviation Safety Assessment (FAA/IASA), audit and none of its carriers have passed the International Air Transport Association/IATA International Safety Audit (IATA/IOSA).

Burkina Faso's existing airport is unsuitable, and the country needs to address capacity constraints and security issues. The immediate challenge for the government is to keep the existing airport in an operational condition, upgrading installations to follow international standards. These short- and mid-term measures could set the ground for stable and increased traffic that might economically justify-in the longer term - the construction of the proposed new airport at Donsin (World Bank/Mott Mac Donald 2009).

Relying on the performance of the surface multimodal route, while an option for international trade in the current situation, is undoubtedly a limited and imperfect option in the longer term, particularly given the government's hopes of diversifying Burkina's economy toward nontraditional products—such as horticulture-and mining. There is much room for improving and expanding air transportation given the demands of the region, and certainly modal diversification beyond surface transport is critical to improving trade and diversifying the economy. 


\section{Water supply and sanitation}

\section{Achievements}

Burkina has made significant progress toward ensuring that all of its population can access improved water. Close to 97 percent of the population gets water through some type of technology, leaving 2.7 percent of the population with surface water. This compares extremely favorably against other African LICs, where, on average, one-third of the population is relying on surface water on a regular basis (table 8). Focusing on what the World Health Organization (WHO) Joint Monitoring Program (JMP) defines as improved water services (piped water, stand posts, and protected wells/boreholes), Burkina has shown impressive progress over the past decade. Overall access to drinking water improved from 59 percent in 2003 to 74 percent in 2007, reaching 79 percent in 2009 (figure 12a).

Table 8. Benchmarking water and sanitation indicators

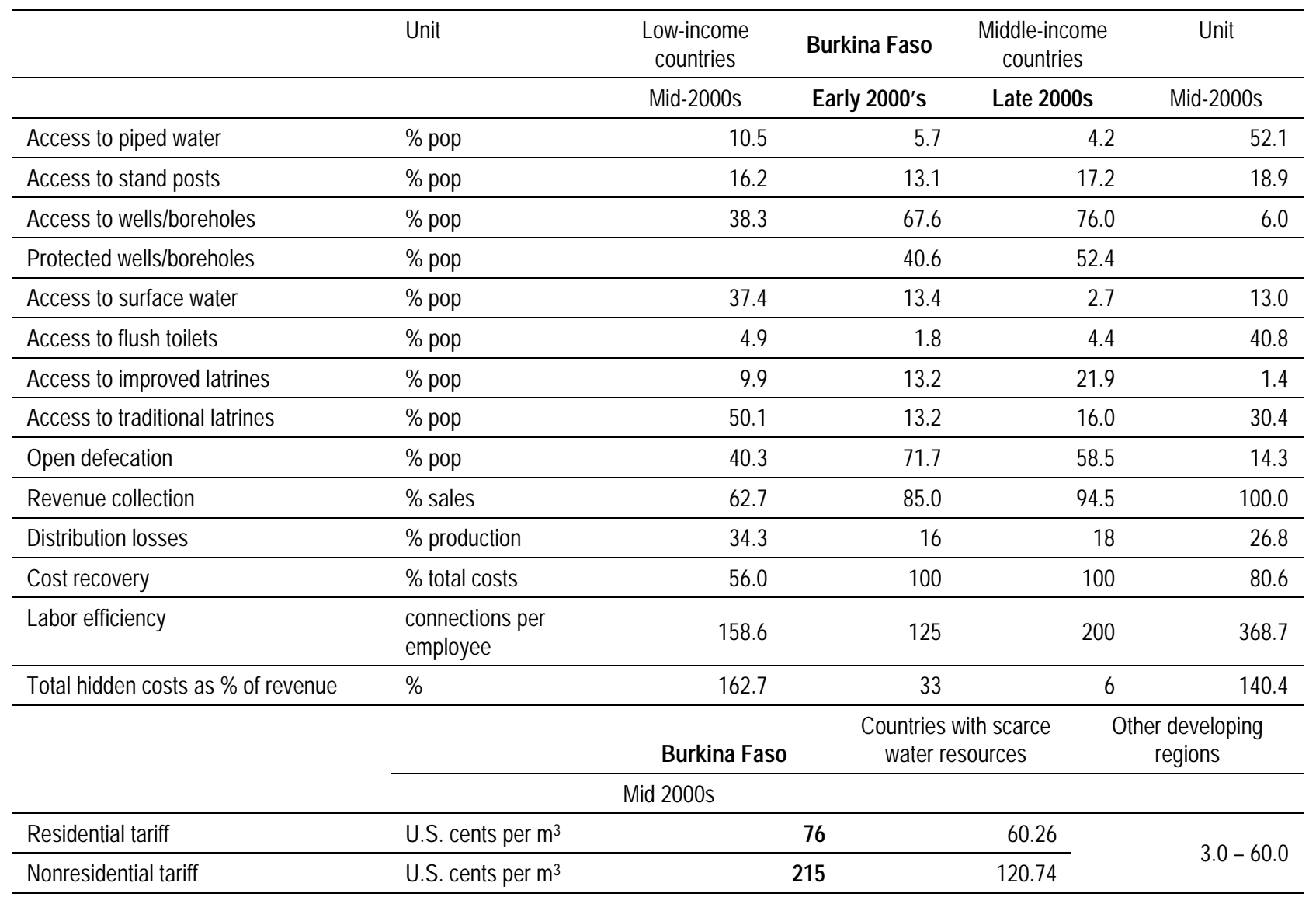

Source: Derived from the AICD national and utility database (www.infrastructureafrica.org/aicd/tools/data).

Progress in providing improved sanitation accelerated after 2003. According to the JMP, less than 20 percent of the Burkinabè population had access to improved sanitation in 2003, while close to two-thirds of the population engaged in open defecation practices. By 2009 close to 50 percent of the population were using latrines and, a small percentage, flush toilets (figure 12b). Yet it is widely accepted that Burkina is running short of meeting the MDG in sanitation. 
Figure 12. Burkina Faso has made progress on improved water supply and sanitation
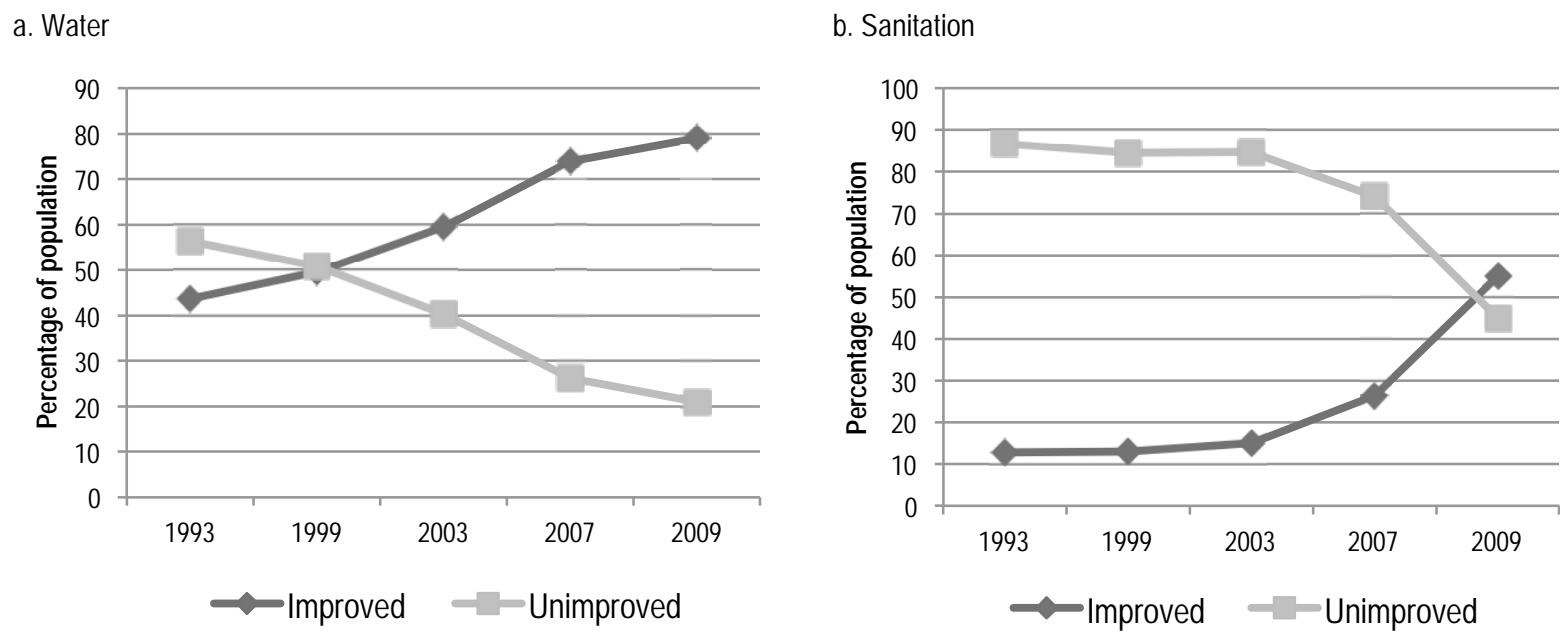

Source: WHO Joint Monitoring Program 2010a and 2010b, from Demographic and Health Surveys for 1993, 1999, and 2003; Questionnaire a Indecateur de Base du Bien-Etre for 2007 and 2009.

Most of the progress in water supply is to be found in urban areas. In 2001 the Office national de l'Eau et l'Assainissement (ONEA), the corporatized public water utility serving urban areas, implemented a performance-based service contract for its commercial and financial activities-without transferring management control to the private sector-linking a portion of the service contractor's revenue to measurable efficiency improvements (Fall and others 2009). The results were impressive. Under a costrecovery tariff, Burkina Faso's ONEA essentially recovered full costs with collection rates. At around $\$ 0.76$ per cubic meter $\left(\mathrm{m}^{3}\right)$ for residential consumers and $\$ 2.15$ per $\mathrm{m}^{3}$ for nonresidential customers, as of 2003 Burkina Faso's water tariffs were substantially higher than those found in other African countries with scarce water resources, yet they were affordable for most of the customers.

Table 9. Evolution of operational indicators associated with ONEA

\begin{tabular}{|c|c|c|c|c|c|c|c|}
\hline Year & $\begin{array}{l}\text { Water delivered } \\
\text { (million } \mathrm{m}^{3} / \text { year) }\end{array}$ & $\begin{array}{c}\text { System losses } \\
(\%)\end{array}$ & $\begin{array}{c}\text { Collection ratio } \\
(\%)\end{array}$ & $\begin{array}{l}\text { Average cost } \\
\qquad\left(\$ / \mathrm{m}^{3}\right)\end{array}$ & $\begin{array}{c}\text { Average } \\
\text { effective tariff } \\
\left(\$ / \mathrm{m}^{3}\right)\end{array}$ & $\begin{array}{l}\text { Total hidden } \\
\text { costs } \\
\text { (\$ million/year) }\end{array}$ & $\begin{array}{l}\text { Total hidden } \\
\text { costs } \\
\text { (\% revenues) }\end{array}$ \\
\hline 2001 & 26 & 15.9 & 85 & 0.89 & 0.86 & 4 & 33 \\
\hline 2002 & 27 & 14.0 & 83 & 0.91 & 1.02 & 5 & 32 \\
\hline 2003 & 28 & 15.2 & 78 & 1.09 & 1.12 & 7 & 31 \\
\hline 2004 & 31 & 17.0 & 88 & 1.14 & 1.16 & 4 & 17 \\
\hline 2005 & 34 & 18.3 & 93 & 1.15 & 1.20 & 3 & 13 \\
\hline 2006 & 37 & 18.0 & 95 & 1.15 & 1.23 & 3 & 8 \\
\hline 2007 & 40 & 18.0 & 95 & 1.15 & 1.23 & 3 & 6 \\
\hline
\end{tabular}

Source: Derived from Briceño-Garmendia, Smits, and Foster (2009).

Distribution losses, at 18 percent of produced water, are almost half of what is observed in utilities in other LICs (34 percent), despite a small increase in unaccounted-for water when the system was expanded (table 8). During the first few years (2001-07) of the service contract implementation in the ONEA service area, urban access to piped water increased from 53 percent to 63 percent, water became available 
on a 24/7 basis in Ouagadougou, the water delivered increased by 70-80 percent, and collection bills from private customers increased from 85 percent to 95 percent (table 9).

With this remarkable performance, ONEA's hidden cost of operational inefficiencies (box 1) has been reduced to nearly zero-making Burkina's utility, by this measure, the most-efficient utility in SubSaharan Africa (figures 13 and 14).

\section{Box 1. Hidden costs in utilities}

A monetary value can be attributed to observable operational inefficiencies-mispricing, unaccounted-for losses, and undercollection of bills, to mention three of the most conspicuous-by using the opportunity costs of operational inefficiencies, that is, tariffs for uncollected bills and production costs for mispricing and unaccountedfor losses. These costs are considered hidden since they are not explicitly captured by the financial flows of the operator. Hidden costs are calculated by comparing a specific inefficiency against the value of that operational parameter in a well-functioning utility (or the respective engineering norm), and multiplying the difference by the opportunity costs of the operational inefficiency.

Source: Briceño-Garmendia, Smits, and Foster 2009.

\section{Figure 13. Evolution of hidden costs in Burkina's water sector}

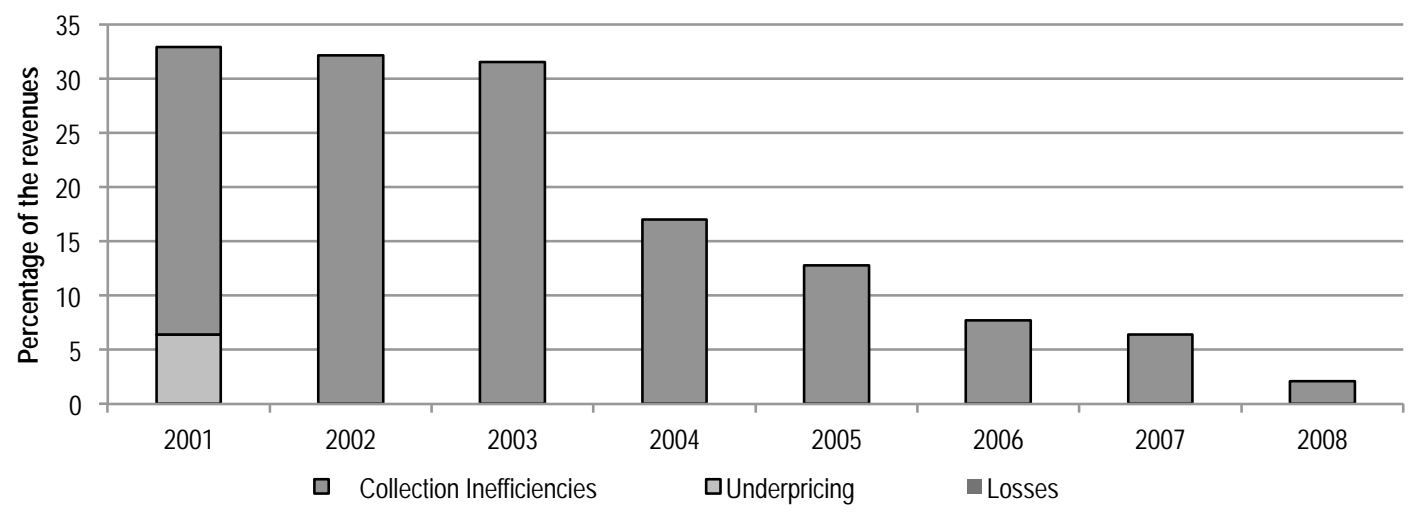

Source: Derived from Banerjee and others (2008).

Figure 14. Hidden costs of selected water utilities, as percentage of the revenues

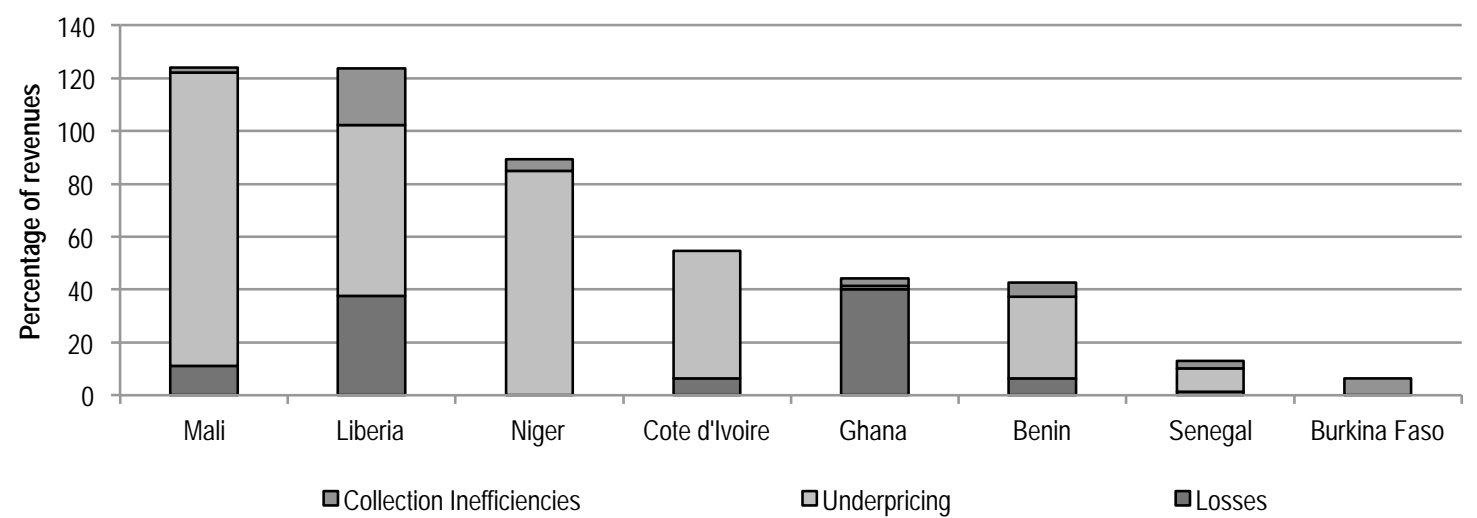

Source: Derived from Briceño-Garmendia, Smits, and Foster (2009). 
The urban-rural service gap has also been reduced. Between the early and late 2000s, the rural-urban gap decreased by 20 percentage points in improved water and about 4 percentage points in sanitation (figure 15). Burkina Faso also adopted important reforms in the rural water and sanitation sector, such as the adoption of a rural water policy, the establishment of a dedicated budget, and the creation of a map of rural water points. At the same time, the country made some initial progress by establishing a rural water fund, introducing a cost-recovery policy, and closing the urban-rural gap.

Figure 15. Urban and rural use of improved water and improved sanitation

a. Trend in urban-rural access to improved water and sanitation

\begin{tabular}{llcccc}
\hline & & $\mathbf{1 9 9 3}$ & $\mathbf{1 9 9 9}$ & $\mathbf{2 0 0 3}$ & $\mathbf{2 0 0 7}$ \\
\hline Improved water & Rural & 38.9 & 43.3 & 52.0 & 69.9 \\
services & Urban & 71.1 & 80.9 & 93.6 & 91.8 \\
& Rural & 7.0 & 6.8 & 7.4 & 18.8 \\
Improved & Urban & 46.7 & 45.1 & 50.5 & 58.2 \\
\hline
\end{tabular}

b. Decrease (increase) in rural-urban gap between early 2000 s and late 2000 s

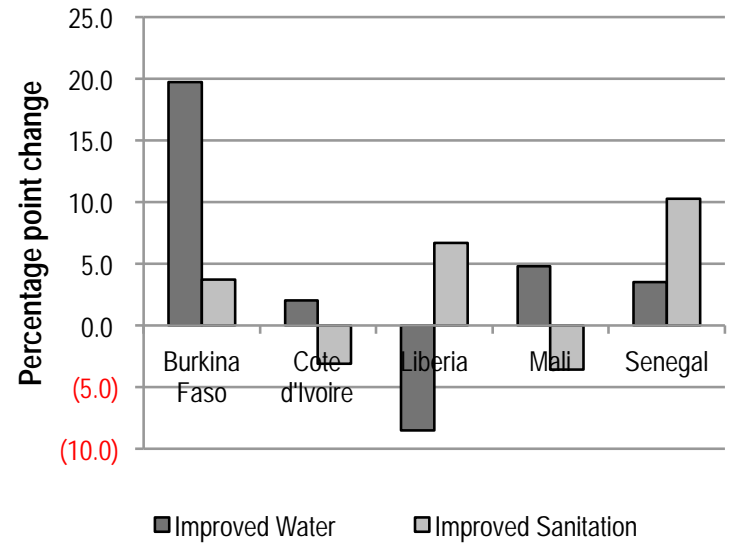

Source: WHO Joint Monitoring Program 2010; for Mali from Demographic and Health Surveys for 1993, 1999, and 2003 and Questionnaire à Indicateur de Base du Bien-Etre for 2007; for other countries from Demographic and Health Surveys for different years.

\section{Challenges}

According to official figures, the country will not reach the MDGs in either water supply or sanitation. In the case of access to improved water, the Burkinabè government reports that 58 percent of the population had access in 2009-against the MDG target of 79 percent in 2015 — which means that it is admittedly off track in achieving the MDG for water supply. On the contrary, figures reported by the JMP present a much more positive view, indicating 79 percent access in 2009 and suggesting that if progress is maintained, the MDG will be comfortably surpassed (table 10).

Table 10. Evolution of operational indicators associated with ONEA

\begin{tabular}{llcr}
\hline \% population with access & & Government & Joint Monitoring Programme \\
\hline \multirow{2}{*}{ Improved water supply } & Rural & 55 & 76 \\
& Urban & 72 & 87 \\
& Total & 58 & 79 \\
Improved sanitation & Rural & - & 54 \\
& Urban & 19 & 57 \\
\hline
\end{tabular}

Source: Government of Burkina Faso 2010; WHO 2010.

$-=$ Not available. 
Both sources agree, however, that the sanitation MDG will not be achieved. In fact, sanitation has become a top priority of the government, whose efforts should only be reinforced.

It becomes clear when comparing the figures from the JMP and the government that one of the challenges facing the sector is the harmonization of the norms used to define "improved" services to water and sanitation. The norms used by the government (National Directorate of Water Supply), ONEA, and the National Statistical Office, not only differ among themselves but also against those of the JMP. Differences include whether access to a service refers to availability or actual use, and whether a temporary malfunction of a facility rules it out as providing service to a community or not. ${ }^{3}$

While progress in urban areas has been remarkable, access to improved water and sanitation in rural areas is less impressive; upcoming challenges include further extending the service to rural areas and improving the technology mix in urban areas, while controlling —if not reducing-costs. This is particularly challenging since gains in access in recent years have been achieved through low-end technologies. On average, increased access to improved water has come from adding wells/boreholes and stand posts while, as a percentage of total population, fewer people have gained access to piped water. Increased access to improved sanitation has come predominantly from more latrines (table 11).

Table 11. Expansion of the safest water and sanitation technologies

a. Water

\begin{tabular}{lcc}
\hline & \multicolumn{2}{l}{$\begin{array}{l}\text { Population gaining access } \\
\text { (per year, \%) }\end{array}$} \\
\hline 1999-2003 & 2003-07 \\
\hline Piped water & 0.7 & $(0.2)$ \\
\hline Stand posts & 1.4 & 1.6 \\
\hline Wells/boreholes & $(0.8)$ & 4.7 \\
\hline Surface water & 2.3 & $(2.2)$ \\
\hline
\end{tabular}

b. Sanitation

\begin{tabular}{lcc}
\hline & \multicolumn{2}{l}{$\begin{array}{l}\text { Population gaining access } \\
\text { (per year, \%) }\end{array}$} \\
\hline 1999-2003 & 2003-07 \\
\hline Flush toilets & 0.3 & 0.7 \\
\hline Improved latrines & 4.4 & 1.7 \\
\hline Traditional latrines & $(2.2)$ & 1.9 \\
\hline Open defecation & 1.0 & $(0.1)$ \\
\hline
\end{tabular}

Source: WHO Joint Monitoring Program 2010 from Demographic and Health Surveys for 1999 and 2003 and Questionnaire à Indicateur de Base du Bien-Etre for 2007.

Extending access to higher-end options, which in the case of water means piped water and stand posts, results in high historical costs. Despite this, ONEA has very successfully achieved cost recoverybut as a consequence, Burkina's tariffs are among the highest in the continent (figure 16). For additional extensions of utility water, while maintaining cost-recovery policies, costs will need to be either controlled or reduced.

\footnotetext{
${ }^{3}$ WSP (2010) discusses the differences among norms in detail.
} 
Figure 16. Water prices in Burkina are among the highest in Africa

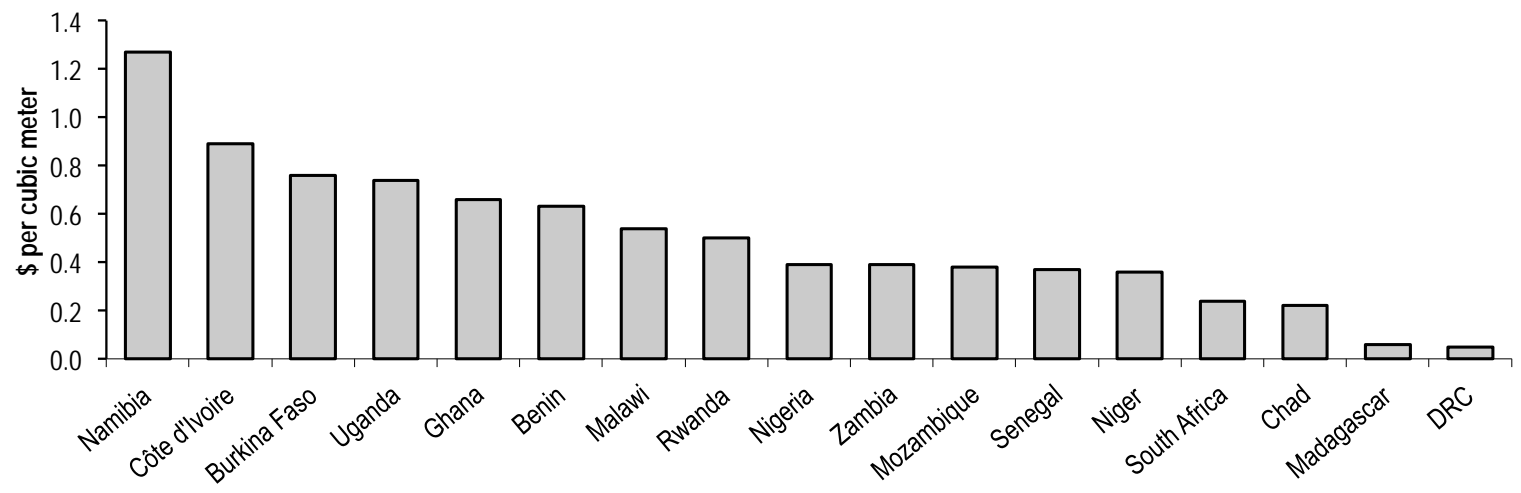

Source: Banerjee and others 2009.

Note: DRC = Democratic Republic of Congo.

\section{Power}

\section{Achievements}

Burkina has taken firm steps to improve the legal and regulatory framework of the energy sector. In November 2007, an electricity law was adopted encouraging private sector -via the involvement of independent power producers - and donor participation in this sector. Also, in recent years, there has been a systematic effort by the Burkinabè authorities to increase power trade with neighbors in the regional West African Power Pool (WAPP). Investment has been carried out to integrate the national power system into a unified regional electricity market by building interconnections with Côte d'Ivoire (the Bobo-Dioblasso-Ouagadougou while facing few delays is already planned to be functional by 2014) and with Ghana (expected to commence in 2011). Nowadays, Burkina imports 15 percent of the electricity consumed. The power capacity from neighbors comes at much lower prices. 
This emphasis on increasing power trade brings benefits on many fronts. From the cost perspective, it is well documented that costs per kilowatt-hour $(\mathrm{kWh})$ of power produced by SONABEL are just short of $\$ 35$ cents, among the highest in Africa, mostly driven by fuel prices. Even with high tariffs, the current level of power costs call for subsidies and represent enormous fiscal costs on the order of $\$ 50$ million per year. Imported electricity has been negotiated for at 7 cents/kWh, less than 20 percent of the cost of domestic production (figure 17). The combination of domestically produced thermal power and cheap imported hydropower will reduce average costs, making current tariffs sufficient to recover costs in the medium term.

Power trade is already bringing additional benefits in terms of reliability and power security, reducing the reliance on a single supplier. More importantly, it diversifies the generation base. Burkina's hydroelectric potential is limited; as a predominantly thermal power producer, the country relies on imported oil (about 400,000-450,000 tonnes annually). However, the full development of West Africa thermal capacity is some years away to materialize in its entirety.

From the demand side, despite the evident need to extend the access and availability of electricity, firms with electricity connections report good satisfaction levels compared to other West African countries. The percentage of sales lost due to power outages is comparable to what is found in other LICs, and the percentage of firms relying on their own generation is well below the Sub-Saharan African average according to the most recent enterprise survey (table 12). 
Table 12. Benchmarking Burkina Faso's power indicators

\begin{tabular}{|c|c|c|c|c|}
\hline & Unit & $\begin{array}{c}\text { Nonfragile, low-income } \\
\text { countries }\end{array}$ & Burkina Faso & $\begin{array}{l}\text { Middle-income } \\
\text { countries }\end{array}$ \\
\hline Installed power generation capacity & MW/million people & 20.2 & 13 & 799 \\
\hline Power consumption & kWH/capita & 107.4 & 44 & 4,479 \\
\hline Firms' reliance on own generator & $\%$ consumption & 21.2 & 1 & 11 \\
\hline Firms' value lost due to power outages & $\%$ sales & 6.5 & 6 & 2 \\
\hline Access to electricity & $\%$ population & 15.0 & 18 & 49.5 \\
\hline Urban access to electricity & $\%$ population & 57.6 & 40 & 74.4 \\
\hline Rural access to electricity & $\%$ population & 3.9 & 3 & 26.3 \\
\hline Growth access to electricity & $\%$ population/year & 0.8 & 5.4 & 12.1 \\
\hline Revenue collection & $\%$ billings & 93.1 & 76 & 100 \\
\hline System losses & $\%$ production & 23.7 & 16 & 20 \\
\hline Cost recovery & $\%$ total cost & 84.4 & 8974 & 85 \\
\hline \multirow[t]{2}{*}{ Total hidden costs as $\%$ of revenue } & $\%$ of revenue & 68.8 & 38 & 6 \\
\hline & & Burkina Faso & Mainly thermal & $\begin{array}{l}\text { Other developing } \\
\text { regions }\end{array}$ \\
\hline
\end{tabular}

Average effective power tariff

U.S. cents

30.0

17.0

$5.0-10.0$

Source: Eberhard and others 2008; World Bank 2007. Derived from the AICD electricity database

(www.infrastructureafrica.org/aicd/tools/data). Outages data from the 2006 and 2009 Enterprise Surveys.

\section{Challenges}

Burkina Faso's power supply is insufficient to meet increasing demand. Installed generation capacity is 13 megawatts (MW) per million people, which represents about 2 percent of the average in Africa's MICs and just about half of the installed generation capacity of other LICs (table 12). Residential power consumption is just one-third of other LICs. Only about 18 percent of the population has access to electricity (about 40 percent in urban areas and 3 percent in rural areas). Per capita consumption is 44 kWh in Burkina Faso, compared with $100 \mathrm{kWh}$ in Cameroon, $200 \mathrm{kWh}$ in Senegal, and $270 \mathrm{kWh}$ in Côte d'Ivoire. The majority of the population (about 90 percent) still relies on wood energy (firewood and charcoal).

Under these circumstances, extending power supply-either by increasing installed capacity or via trade-is at the top of the government agenda. Improving the operational efficiency of SONABEL and revising the prevalent tariff scheme are also necessary before or as part of the expansion process.

In recent years, SONABEL has faced system transmission and distribution losses of over 60 percent, much higher than the internationally accepted norm of 10 percent. In addition, tariffs barely recover the operating costs of the expensive SONABEL power (table 13). The hidden costs of these operational inefficiencies (box 1) are approximately equivalent to 37 percent of SONABEL's revenues. These hidden costs, though lower than the average in low-income African countries represent a significant burden for the expansion plan of the sector (table 12). 
Table 13. Evolution of hidden costs associated with SONABEL

\begin{tabular}{|c|c|c|c|c|c|c|c|}
\hline & $\begin{array}{c}\text { Energy } \\
\text { produced/purchased } \\
\text { (GWh/year) }\end{array}$ & $\begin{array}{l}\text { System } \\
\text { losses (\%) }\end{array}$ & $\begin{array}{c}\text { Implicit } \\
\text { collection ratio } \\
(\%)\end{array}$ & $\begin{array}{l}\text { Average total } \\
\text { cost }(\$ / k W h) t\end{array}$ & $\begin{array}{c}\text { Average } \\
\text { effective tariff } \\
(\$ / k W h)\end{array}$ & $\begin{array}{l}\text { Total hidden } \\
\text { costs }(\$ \\
\text { million/year) }\end{array}$ & $\begin{array}{l}\text { Total hidden } \\
\text { costs (\% } \\
\text { revenues) }\end{array}$ \\
\hline 2007 & 736 & 18 & 91 & 0.35 & 0.29 & 70 & 46 \\
\hline 2008 & 755 & 16 & 91 & 0.35 & 0.31 & 57 & 37 \\
\hline
\end{tabular}

Source: Derived from Eberhard and others (2008) and Briceno-Garmendia and Shkratan (2010).

Note: $\mathrm{GWh}=$ gigawatt-hour; $\mathrm{kWh}=$ kilowatt-hour.

While high by continental standards, SONABEL's hidden costs look modest in the West African context, which says more about Burkina's neighbors' operational inefficiencies than about SONABEL's efficiency. In any case, what is extremely relevant is that no expansion in access will succeed if measures are not taken beforehand to reduce these economic losses (figure 18).

Figure 18. Hidden costs of power utilities in selected West African countries, as percentage of the revenues

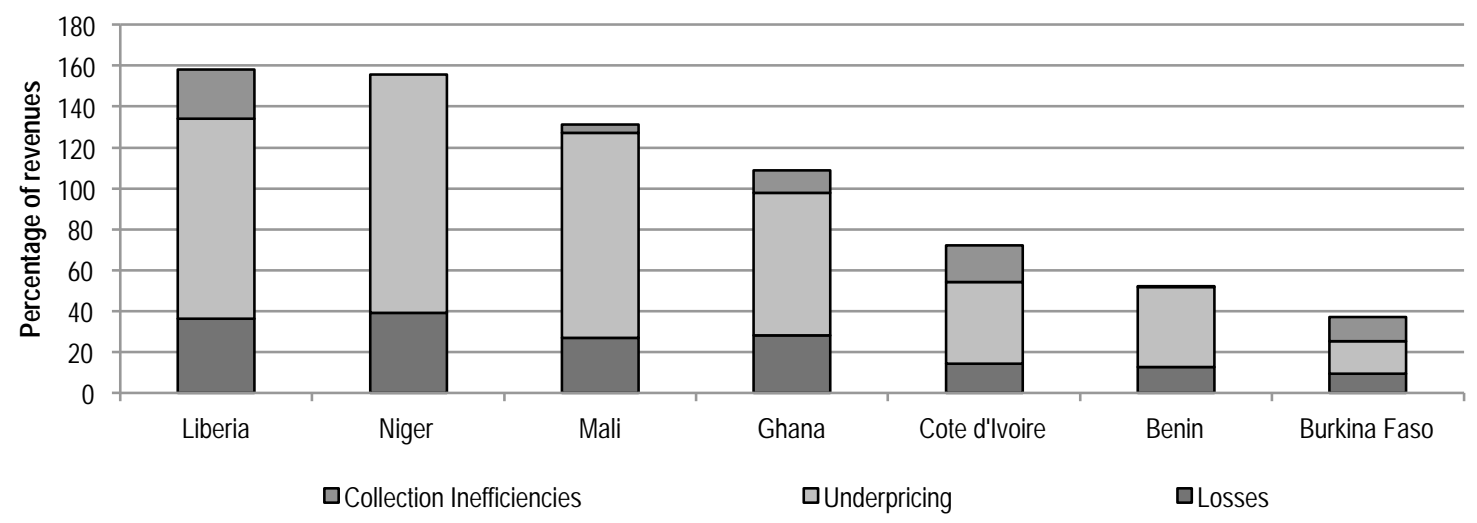

Source: Derived from Briceño-Garmendia, Smits, and Foster (2009).

Going forward, the high cost of power in Burkina is one of the country's most salient challenges. The cost of power in Burkina - around $\$ 35$ cents per $\mathrm{kWh}$ - is significantly higher than in similar countries (figure 19). This is because Burkina's power costs are pegged to international oil prices, given its predominantly thermal-based generation capacity, and are prone to additional markups related to transport. Burkina has no known reserves of hydrocarbons (oil, gas, or coal) and relies on distant coastal ports (more than $1,000 \mathrm{~km}$ away) for fuel imports to meet both its transport and power generation needs, which are currently in excess of half a million tonnes annually.

This poses a long-term challenge, and fostering power trade in the medium run is the most practical solution to lowering costs. Yet, Burkina needs to eliminate distortions created by the existing subsidy mechanism to promote more efficient consumption patterns, harmonize with the WAPP, achieve regional integration, and thus increasingly add cheaper imported electricity to the consumed electricity mix. Unfortunately, even with the existing subsidies, power prices in Burkina are among the highest in Africa (figure 20). 
Figure 19. Burkina's power costs are among the highest in Africa

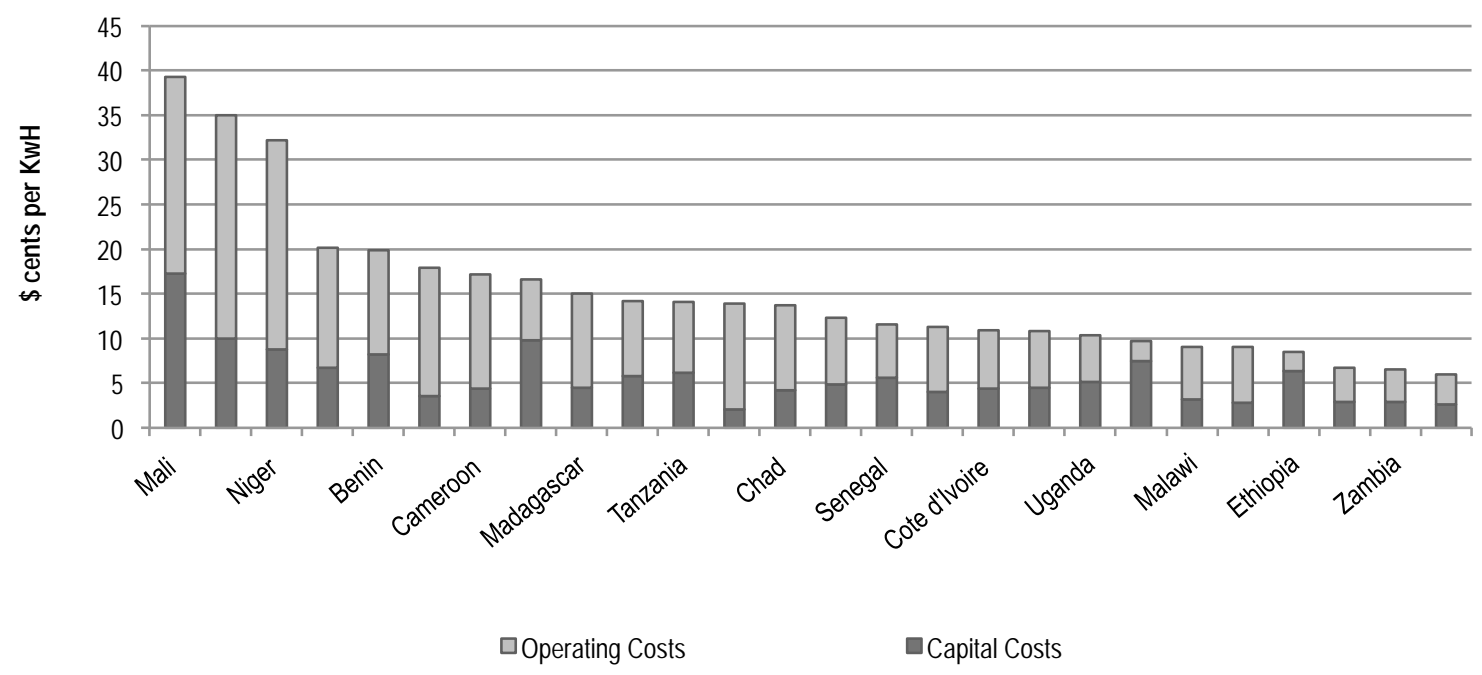

Source: Eberhard and others 2008.

Figure 20. Power price in Burkina are among the highest in Africa

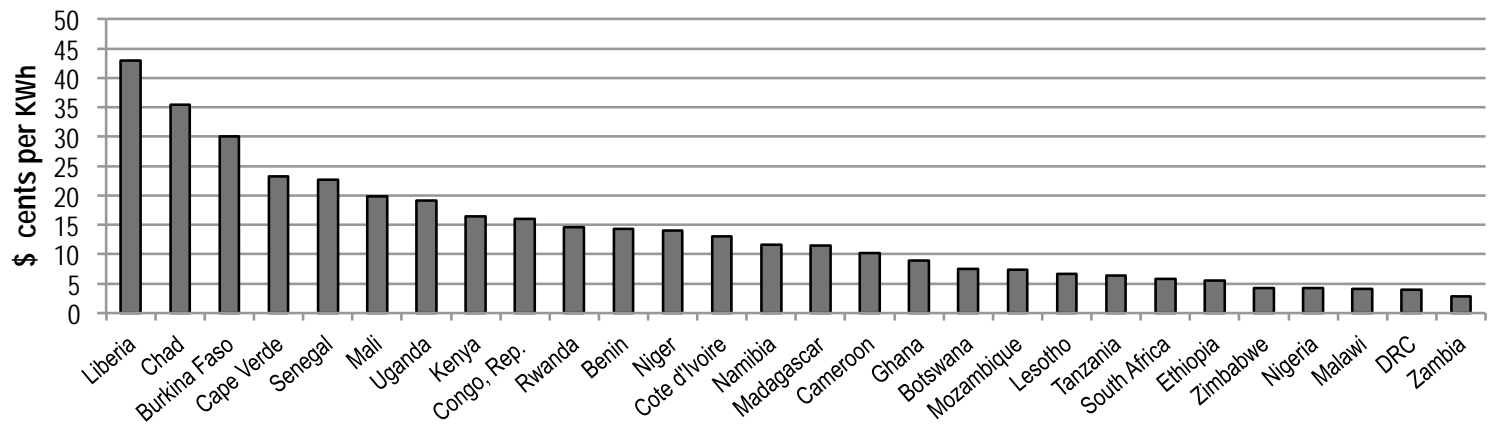

Source: Briceño-Garmendia and Shkaratan 2010.

\section{Information and communication technologies}

\section{Achievements}

Compared with peers, the GSM coverage is larger than in other LICs, while penetration is average. The coverage of the mobile network increased from 19 percent of the population in 2001 to over 60 percent in 2007. Mobile penetration increased from 5.3 users per 100 habitants in 2005 to 16.8 in 2007, and to 29 users in 2009 (table 14).

The Internet market also expanded significantly (figure 21). In 2005 the number of Internet users per 1,000 people was 0.187 , and the international Internet bandwidth (bits per second per person) was 0.006 ; in 2007 these figures increased dramatically to 7.5 and 14.6 , respectively. 
BURKINA FASO’S INFRASTRUCTURE: A CONTINENTAL PERSPECTIVE

Table 14. Benchmarking ICT indicators

\begin{tabular}{|c|c|c|c|c|c|}
\hline & \multirow[t]{2}{*}{ Unit } & \multirow{2}{*}{$\begin{array}{c}\text { Nonfragile, low- } \\
\text { income countries }\end{array}$} & \multicolumn{2}{|c|}{ Burkina Faso } & \multirow{2}{*}{$\begin{array}{c}\text { Middle-income } \\
\text { countries } \\
2005 \\
\end{array}$} \\
\hline & & & 2005 & 2007-0) & \\
\hline GSM coverage & $\%$ population under signal & 48 & 41 & 61 & 97 \\
\hline International bandwidth & Mbps/capita & 6 & 5.8 & 14.6 & 30 \\
\hline Landline & Subscribers/100 people & 1 & 0.7 & 0.9 & 9 \\
\hline Mobile phone & Subscribers/100 people & 15 & 5.3 & 16.8 & 87 \\
\hline US dollars & $\begin{array}{c}\text { Burkina Faso } \\
2007\end{array}$ & $\begin{array}{l}\text { Countries without } \\
\text { submarine cable }\end{array}$ & $\begin{array}{l}\text { Countrie } \\
\text { submarir }\end{array}$ & $\begin{array}{l}\text { es with } \\
\text { e cable }\end{array}$ & $\begin{array}{l}\text { Other developing } \\
\text { regions }\end{array}$ \\
\hline Price of monthly mobile basket & 14.6 & 11.1 & & 11.12 & 9.9 \\
\hline Price of monthly fixed-line basket & 11.2 & 13.6 & & 13.58 & - \\
\hline Price of 20-hour Internet package & 90.5 & 68.0 & & 47.00 & 11.0 \\
\hline Price of a call to the United States per minute & 0.4 & 0.86 & & 0.48 & 0.66 \\
\hline Price of an inter-Africa telephone calls per minute & 1.6 & 0.7 & & 0.57 & n.a. \\
\hline
\end{tabular}

Source: Mali 2005 data together with benchmarks are taken from the AICD database. Mali 2007-08 data are compiled from a variety of World Bank sources (including an information and communication technology for development database) to give a sense of the progress made during the past four to five years; Ampah and others 2009; AICD national database (www.infrastructureafrica.org/aicd/tools/data).

Note: Numbers reported in the table as of 2007. GSM = global system for mobile communications; Mbps = megabits per second.

$-=$ Not available.

n.a. $=$ Not applicable.

\section{Figure 21. Impressive expansion of the Internet market in Burkina Faso}

a. Internet service trends

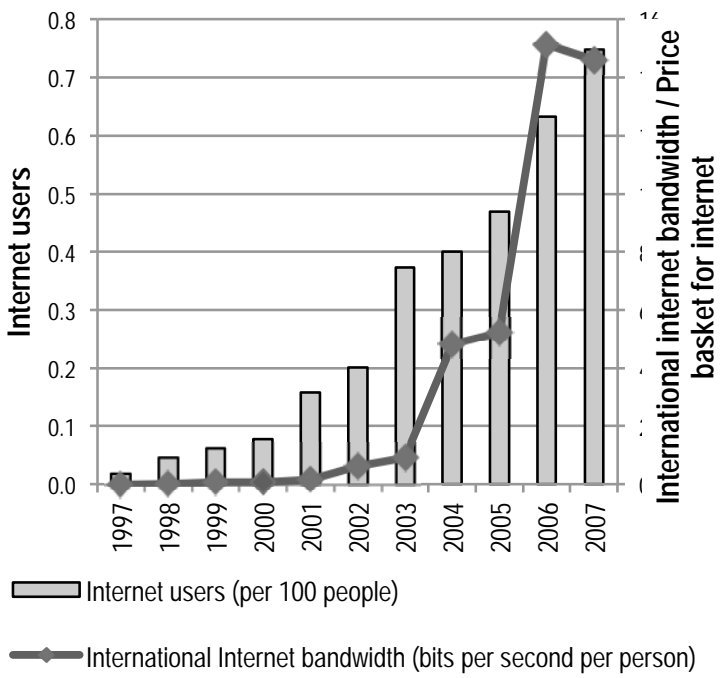

b. Benchmarked against West African peers

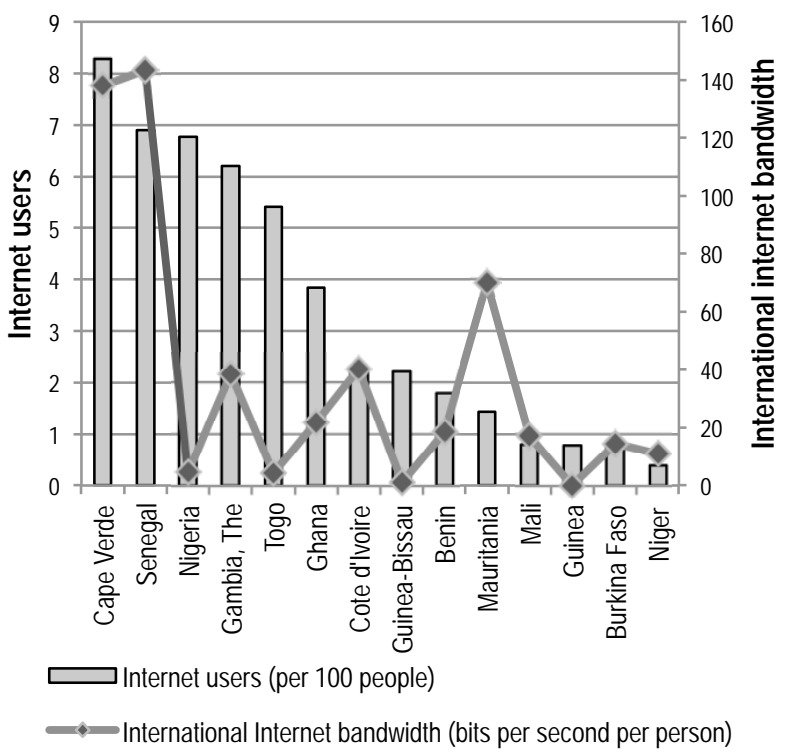

Source: World Bank, including AICD analysis. 
Key institutional reforms are behind this progress.

Liberalizing the market and opening to private capital have been instrumental. In the early 2000s the mobile market was monopolistic; in 2005 there were three operators in the market and a fourth expected by the end of 2010. The national operator, Onatel, was privatized in 2006, when Burkina Faso's government sold a 51 percent stake to Maroc Telecom. As of 2009, the government sold a further 20 percent of Onatel's capital in a public offering and
Figure 22. Market concentration in Burkina Faso relatively low

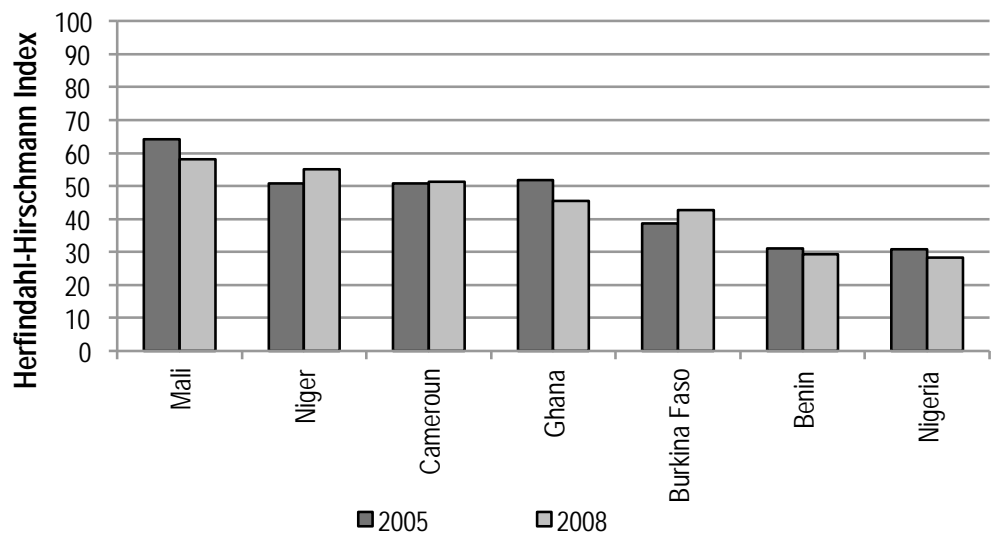

Source: World Bank 2009a.

Note: Herfindhal-Hirschmann index (HHI) is a commonly accepted measure of market concentration. It is calculated by squaring the market share of each firm competing in the market and then summing the resulting numbers. A HHI of 100 indicates the market is a monopoly; the lower the $\mathrm{HHI}$, more diluted is the market power exerted by one company/agent. an additional 6 percent was expected to be sold to employees. Burkina Faso has one of the lowest market power concentrations in West Africa (figure 22).

Flows of private resources to the sector in the period 1992 99 were minimal, at an annual average of $\$ 0.001$ million, but they skyrocketed in subsequent years: private participation increased sixfold between the periods 2000-03 and 2004-08, partly due to significant progress in Burkina Faso's investing climate. It is likely that another 35 percent of the GSM signal could be profitably served by private operators. Only about 5 percent of the population would not be
Figure 23. There is still room for increased private participation

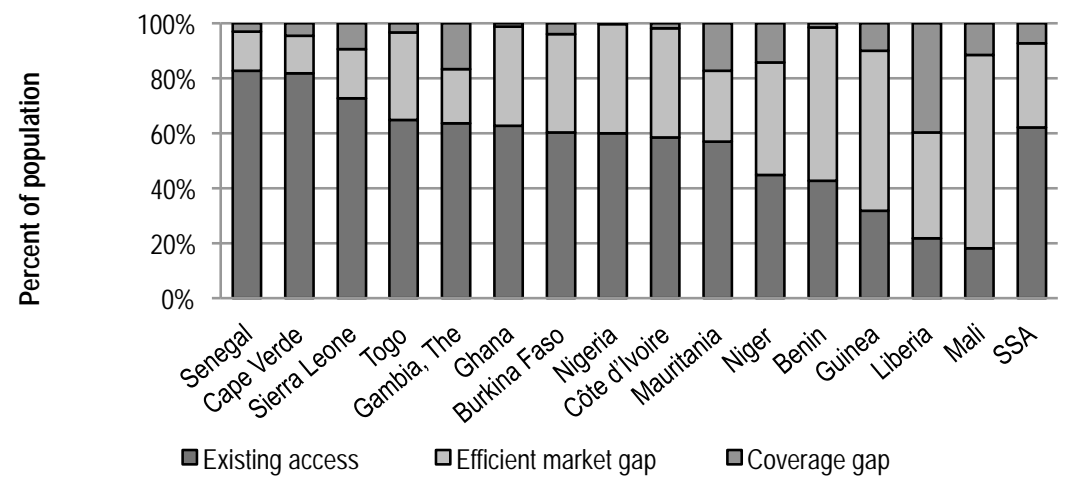

Source: Mayer and others 2009.

Note: Existing access represents the percentage of the population currently covered by voice infrastructure as of the third quarter of 2006. The efficient market gap represents the percentage of the population for whom voice telecommunications services are commercially viable given efficient and competitive markets. The coverage gap represents the percentage of the population for whom services are not viable without subsidy. commercially viable to serve and would probably require some degree of public subsidy (figure 23).

For the so-called coverage gap (that is, the percentage of the population for whom services are not viable without a subsidy), a universal access fund of about $\$ 20$ million was set up with funds from operators to support rollout of services in rural areas. But this has remained largely unused, pending approval of the revised Universal Access Strategy. The government is finalizing a detailed national backbone feasibility study, which will provide guidance on development and financing options for a more robust national ICT infrastructure (figure 24). 
Figure 24. Telecommunications coverage in Burkina Faso

a. Telephony
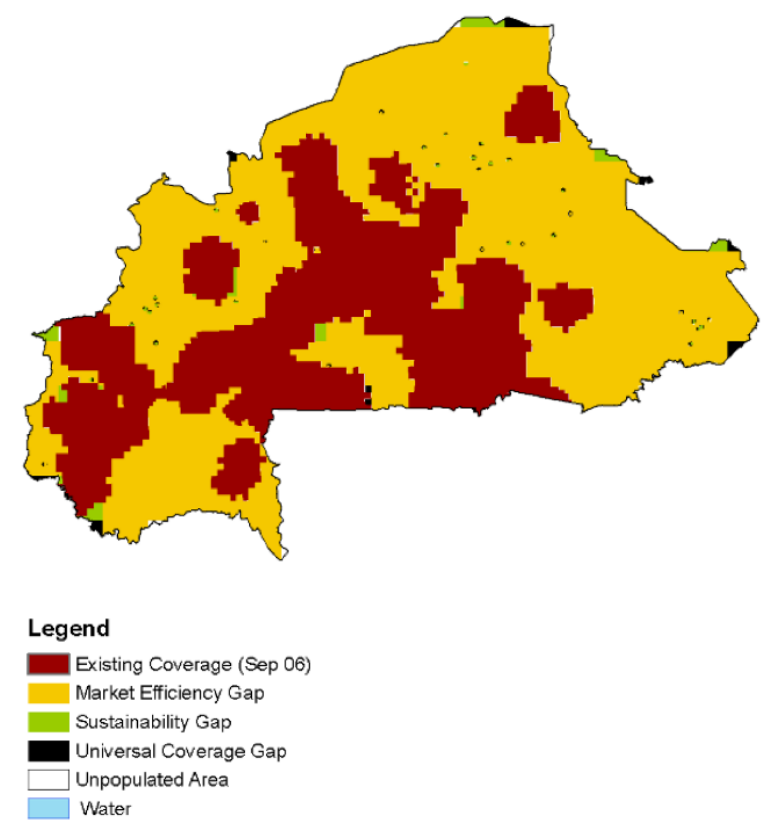

b. Broadband
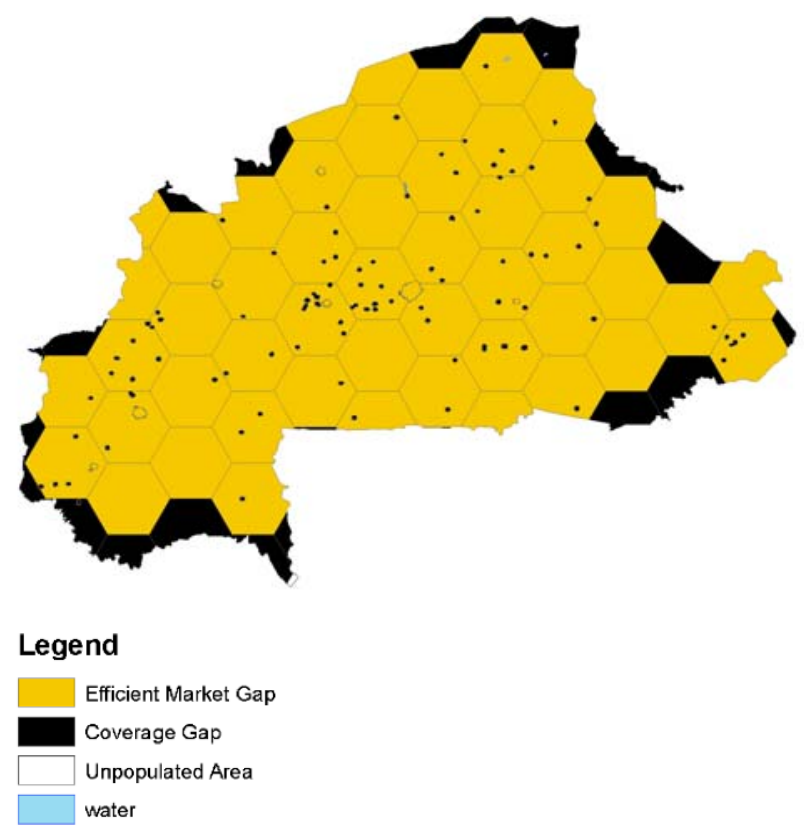

Source: Mayer and others 2009.

\section{Challenges}

Charges for mobile and inter-Africa international calling are higher in Burkina Faso than in other African countries without a submarine cable (table 15). Mobile prices might be increased as a consequence of the charges levied by the government to renew licenses, which account for about $\$ 58$ million. High prices of calls within Africa are partially due to the fact that international connectivity is still largely satellite based, and the only indirect existing link through Côte d'Ivoire suffers from continuous instability and frequent outages. The international gateway is still monopolized by Onatel. Internet charges remain relatively high (despite the fact that the price of a 20-hour internet package dropped substantially between 2005 and 2006, from $\$ 90$ to $\$ 75)$.

Submarine cables could substantially reduce costs as long as access is competitive (table 15). Based on experience elsewhere in Africa, the completion of the submarine cable project South Atlantic 3/West Africa Submarine Cable (SAT-3/WASC) in 2002 has the potential to cut Burkina Faso's Internet and international telecommunications charges in half, as long as the neighboring costal countries develop the infrastructure to connect to it. But because access to the international gateway has been monopolized by a group of incumbent operators, there has not been competition between alternate landing stations. Also, new entrants and Internet service providers (ISPs) face predatory practices and unaffordable prices.

Countries such as Burkina Faso-with access to a submarine cable for which the international gateways remain under monopolistic control-do not experience full price reductions from increases in international connectivity, essentially because the benefits of the technology are retained as monopoly profit (table 15). 
Table 15. High international call charges driven both by technology and market power

\begin{tabular}{lcccc}
\hline$\$$ & $\begin{array}{c}\text { Call within } \\
\text { region }\end{array}$ & $\begin{array}{c}\text { Call to the } \\
\text { United States }\end{array}$ & $\begin{array}{c}\text { Internet } \\
\text { dial-up }\end{array}$ & $\begin{array}{c}\text { Internet } \\
\text { ADSL }\end{array}$ \\
\hline Without submarine cable & 1.34 & 0.86 & 68 & 283 \\
\hline With submarine cable & 0.57 & 0.48 & 47 & 111 \\
$\quad$ Monopoly on international gateway & 0.70 & 0.72 & 37 & 120 \\
$\quad$ Competitive international gateway & 0.48 & 0.23 & 37 & 98 \\
\hline
\end{tabular}

Source: Minges and others 2009.

Note: $\mathrm{ADSL}=$ asymmetric digital subscriber line.

\section{Financing Burkina Faso's infrastructure}

To meet its most pressing infrastructure needs and catch up with developing countries in other parts of the world, Burkina Faso needs to expand its infrastructure assets in key areas (table 16). The targets outlined in table 16 are purely illustrative, but they represent a level of aspiration that is not unreasonable. Developed in a standardized way across African countries, they allow for cross-country targets that can be modified or delayed as needed to achieve financial balance.

Table 16. Illustrative investment targets for infrastructure in Burkina Faso

\begin{tabular}{lll}
\hline & Economic target & Social target \\
\hline ICT & $\begin{array}{l}\text { Install fiber-optic links to neighboring capitals and the } \\
\text { submarine cable. }\end{array}$ & $\begin{array}{l}\text { Provide universal access to the GSM signal and } \\
\text { public broadband facilities. }\end{array}$ \\
\hline Power & New generation capacity and interconnectors. & $\begin{array}{l}\text { Increase electrification to 23 percent (100 percent } \\
\text { urban and 6 percent rural). }\end{array}$ \\
\hline Transport & $\begin{array}{l}\text { Achieve regional (national) connectivity with good-quality } \\
\text { two-lane (or one-lane) paved road. }\end{array}$ & $\begin{array}{l}\text { Provide rural road access to 25 percent of the } \\
\text { highest-value agricultural land, and urban road } \\
\text { access within 500 meters. }\end{array}$ \\
\hline WSS & n.a. & $\begin{array}{l}\text { Achieve Millennium Development Goals, clear sector } \\
\text { rehabilitation backlog. }\end{array}$ \\
\hline
\end{tabular}

Source: Mayer and other 2009; Rosnes and Vennemo 2009; Carruthers, Krishnamani, and Murray 2009; You and others 2009.

Note: ICT = information and communication technology; WSS = water supply and sanitation; GSM = global system for mobile communications. n.a. $=$ Not applicable.

Meeting these illustrative infrastructure targets for Burkina Faso would cost $\$ 613$ million annually through 2015. Capital expenditure would account for 65 percent of this requirement. Requirements for transport, at $\$ 144$ million per year, are calculated on the basis of achieving regional connectivity with a good-quality two-lane paved road, and provide rural road access to 25 percent of the rural population and urban road access within 500 meters. Improving power access will require an estimated $\$ 142$ million per year to increase the electrification rate to 23 percent at the national level. The water and sanitation sector has the highest spending needs: almost $\$ 208$ million will be needed each year to meet the MDGs, with capital expenditure accounting for three-quarters of the total. While less than the amounts needed for these sectors, requirements for ICT are also high in absolute terms, amounting to around $\$ 120$ million per year (table 17). 
Table 17. Indicative infrastructure spending needs in Burkina Faso, 2006-15

\begin{tabular}{lccc}
\hline \$ million per year & & & \\
\hline Sector & Capital expenditure & Operation and maintenance & Total needs \\
\hline ICT & 87 & 32 & 119 \\
\hline Power (nontrade) & 71 & 71 & 142 \\
\hline Transport (basic) & 81 & 64 & 144 \\
\hline WSS & 157 & 50 & 208 \\
\hline Total & 396 & 218 & 613 \\
\hline
\end{tabular}

Source: Mayer and others 2009; Rosnes and Vennemo 2009; Carruthers, Krishnamani, and Murray 2009; You and others 2009. Derived from models that are available online at www.infrastructureafrica.org/aicd/tools/models.

Note: ICT = information and communication technology; WSS = water supply and sanitation.

Burkina Faso's infrastructure spending needs are low in absolute terms - and even more so relative to GDP (figure 25). At $\$ 613$ million, in absolute terms, the country's needs are among the lowest in West Africa. Relative to the size of Burkina Faso's economy, that spending would amount to 11 percent of GDP. Investment alone would absorb around 7 percent of GDP, which is less than the 14 percent of the GDP China invested in infrastructure during the mid-2000s.

\section{Figure 25. Burkina Faso's infrastructure spending needs are greater than those of comparable countries}

Estimated infrastructure spending needed to meet targets, as percentage of GDP

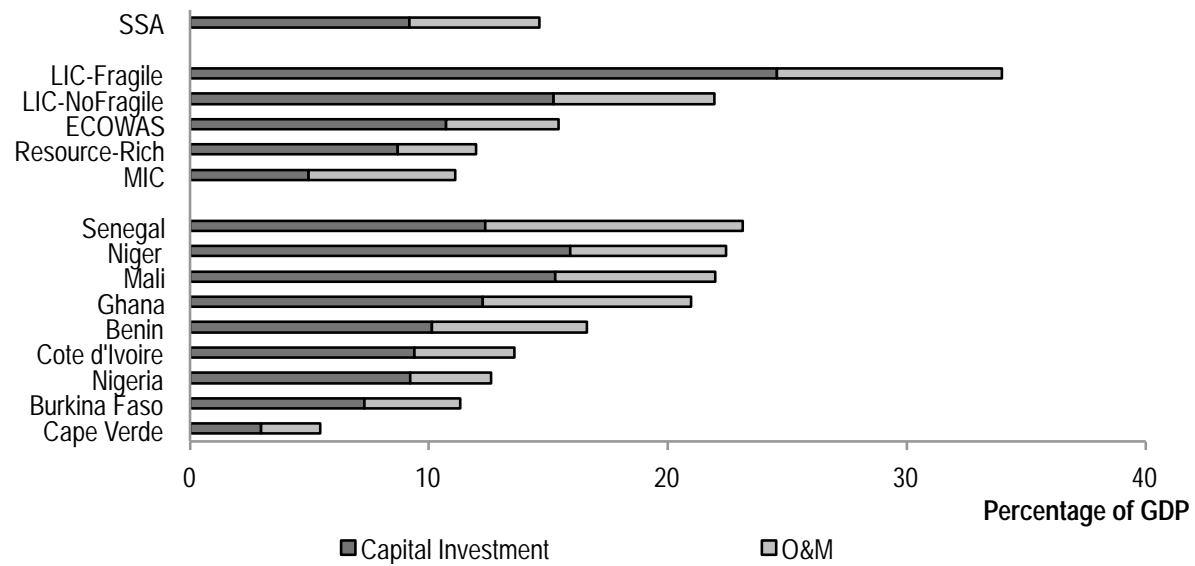

Source: Foster and Briceño-Garmendia 2009.

Note: LIC = low-income country; MIC = middle-income country; ECOWAS = Economic Community of West African States; SSA = Sub-Saharan Africa; GDP = gross domestic product; O\&M = operations and maintenance.

Burkina Faso already spends a sizable amount ( $\$ 406$ million per year) to meet its infrastructure needs (table 18). About 70 percent of the total is allocated to capital expenditure and 30 percent to operating expenditures. Operating expenditure is entirely covered from budgetary resources and payments by infrastructure users. The largest source of funding for infrastructure investment is overseas development, which accounts for 40 percent of the total amount. The private sector accounts for a further 30 percent of current capital expenditure. The contribution of the public sector in financing capital investment is 17 percent, whereas the contribution of non-OECD countries is only about 7 percent. Water, sanitation, and power capture almost 90 percent of the resources allocated to operating expenditures. Private participation 
in ICT accounts for almost 65 percent of all private participation in the country's infrastructure. Water and sanitation received almost 35 percent of private investment in the country, and power a conspicuously small percentage.

Table 18. Financial flows to Burkina Faso infrastructure, average 2001-06

$\$$ million per year averaged over 5-year period

\begin{tabular}{lccccccc} 
& \multicolumn{5}{c}{ Capital investment } \\
\cline { 3 - 8 } & $\begin{array}{c}\text { O\&M } \\
\text { (public) }\end{array}$ & Public & ODA & $\begin{array}{c}\text { Non-OECD } \\
\text { Financiers }\end{array}$ & PPI & $\begin{array}{c}\text { Total, capital } \\
\text { investment }\end{array}$ & $\begin{array}{c}\text { Total } \\
\text { spending }\end{array}$ \\
\hline ICT & 10 & 2 & 6 & 1 & 64 & 73 & 83 \\
\hline Power & 59 & 10 & 33 & 1 & 0 & 44 & 103 \\
\hline Transport & 0 & 35 & 45 & 21 & 0 & 100 & 100 \\
\hline WSS & 46 & 3 & 37 & 0 & 33 & 119 \\
\hline Total & 115 & 50 & 121 & 22 & 97 & 291 \\
\hline
\end{tabular}

Source: Derived from Foster and Briceño-Garmendia (2009).

$\mathrm{O} \& \mathrm{M}=$ operations and maintenance; $\mathrm{ODA}=$ official development assistance; $\mathrm{PPI}=$ private participation in infrastructure; $\mathrm{CAPEX}=$ capital expenditure; OECD = Organisation for Economic Co-operation and Development; WSS = water supply and sanitation; ICT = information and communication technology.

Burkina Faso's current spending on infrastructure is also a relatively small share of its GDP when compared to its peers. Burkina Faso spends 7.5 percent of its GDP on infrastructure, the level of other nonfragile LICs (figure 26), but the pattern of its investments is different. Burkina Faso's public sector invests substantially more in power but less in ICT and transport than its African peers.

Figure 26. Spending allocated to address infrastructure needs

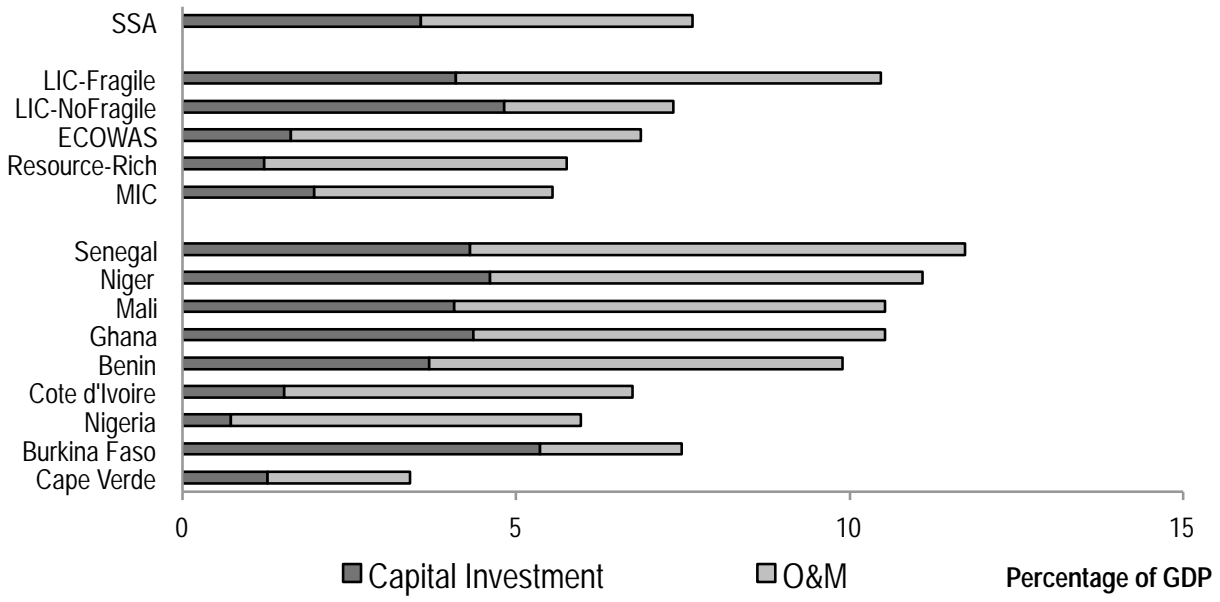

Source: Foster and Briceño-Garmendia 2009.

Note: LIC = low-income country; MIC = middle-income country; ECOWAS = Economic Community of West African States; SSA = SubSaharan Africa; O\&M = operations and maintenance.

For power, transport, and water supply and sanitation, the pattern of finance is similar to the peer group, with a mix of public and donor finance. Burkina Faso's state-owned enterprises finance most of the operations and maintenance, particularly in the power sector, whereas the government finances most 
of the capital expending. In fact, capital investment in the transport sector is exclusively financed by the central budget (figure 27).

Figure 27. O\&M is predominantly financed by state-owned enterprises; investments by the central government

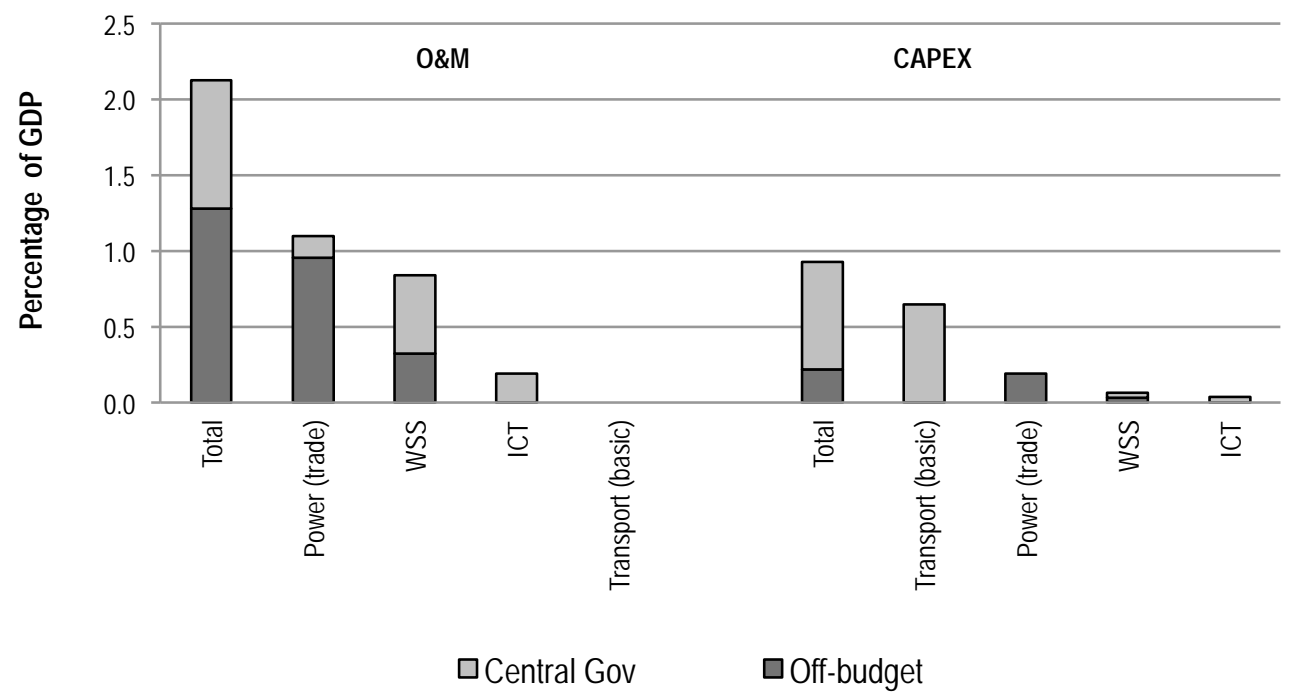

Source: Derived from Briceño-Garmendia, Smits, and Foster (2009).

Note: WSS = water supply and sanitation; ICT = information and communication technology; GDP = gross domestic product; O\&M = operations and maintenance; CAPEX = capital expenditure.

\section{How much more can be done within the existing resource envelope?}

About $\$ 83$ million of additional resources could be recovered each year by improving efficiency (table 19). The three largest potential sources of efficiency gains are (i) improving the cost recovery of utilities, (ii) increasing bill collections, and (iii) reducing distributional losses. The power sector promises the highest potential efficiency dividends.

Table 19. Potential gains from greater operational efficiency

\begin{tabular}{lccccc}
\hline & ICT & Power & Transport & WSS & Total \\
\hline Underrecovery of costs & - & 37 & Na. & 0 & 37 \\
\hline Overstaffing & n.a. & 10 & - & 2 & 12 \\
\hline Distribution losses & - & 17 & - & 0 & 17 \\
\hline Undercollection & - & 16 & Na. & 1 & 17 \\
\hline Low budget execution & 0 & 0 & 0 & 0 & 1 \\
\hline Total & 0 & 80 & 0 & 3 & 83 \\
\hline $\begin{array}{l}\text { Source: Derived from Foster and Briceño-Garmendia (2009). } \\
\text { Note: WSS = water supply and sanitation; ICT = information and communication technology. }\end{array}$ \\
$\begin{array}{l}-=\text { Not available. } \\
\text { n.a. }=\text { Not applicable. }\end{array}$
\end{tabular}


In the water sector, it is estimated that as of 2008 the average total cost of producing utility water was $\$ 1.15$ per $\mathrm{m}^{3}$ (including capital costs), while the average residential effective tariff was $\$ 1.22$. As a result, ONEA managed to cover 100 percent of its operating and capital costs (figure 28).

In the power sector, the burden of underpricing was 0.55 percent of GDP; average effective tariffs, at $\$ 35$ cents per $\mathrm{kWh}$, were not enough to cover operating and capital costs (the estimated costrecovery tariff is $\$ 0.42$ per $\mathrm{kWh}$ ). Looking ahead to the future, the long-run marginal cost of power in Burkina Faso could fall from 26 cents to 25 cents once power-trading agreements materialize. These developments should lower prices charged to end users as well as ease the pressure on national budgets.

Access to electricity and safe water services in Burkina Faso is not equitable (figure 29). The poorest quintiles of the population do not have access to utility water, whereas 34 percent of the richest quintile has access to piped water and 47 percent to stand posts. On the other hand, the poorest households are served mainly by wells or boreholes ( 65 percent of the quintile 1 and 83 percent of the quintile 2 ). The poorest people are the ones using the most surface water (34 percent of the quintile 1 and 16.5 percent of the quintile 2$)$, whereas the richest population barely uses surface water (0.04 percent of the quintile 5). On the sanitation side, less than 1 percent of the poorest quintile of the population has access to any form of sanitation, which implies that 99.6 percent uses open defecation. The richest quintile is the one with the highest access to flush toilets (at 9.02), traditional latrines (at 10.34), and VIP/San Plat/chemical latrines (at 74.35). Fifty-seven percent of households with access to the power grid are in the richest quintile (figure 29). 
Figure 29. Burkina Faso's consumption of infrastructure services is highly differentiated by budget

a. Mode of water supply, by income quintile

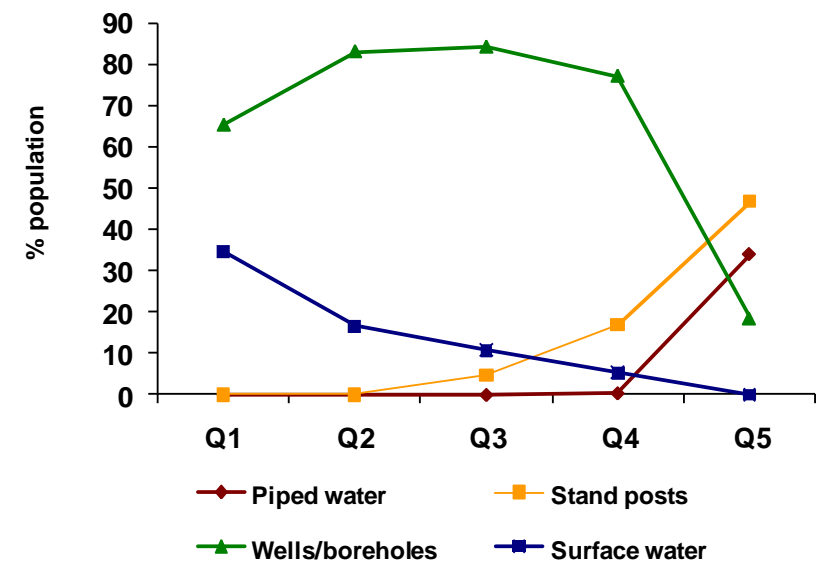

b. Mode of sanitation, by income quintile

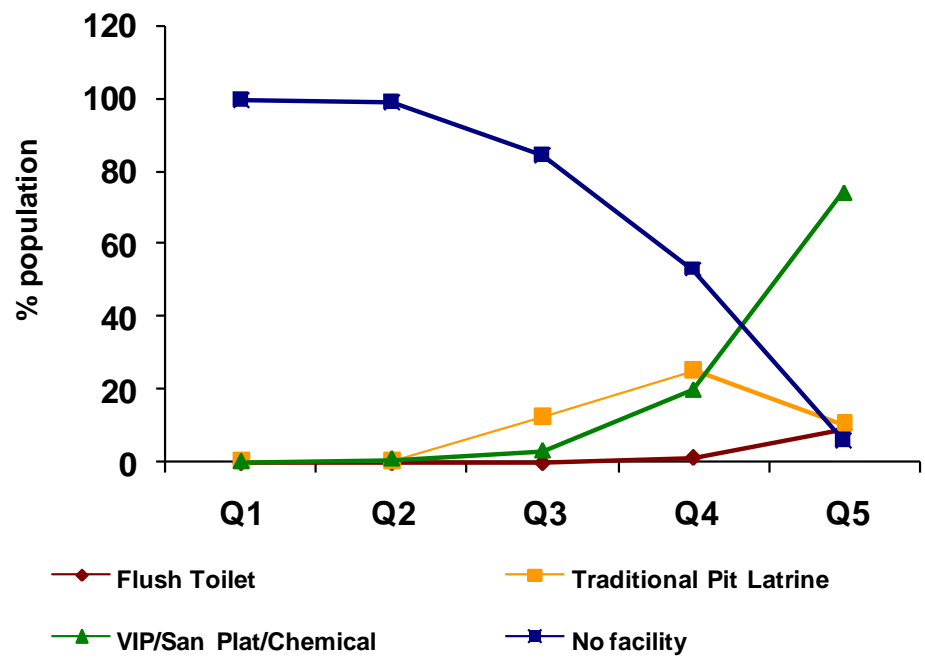

c. Prevalence of connection to power grid among Burkina Faso population, by income quintile

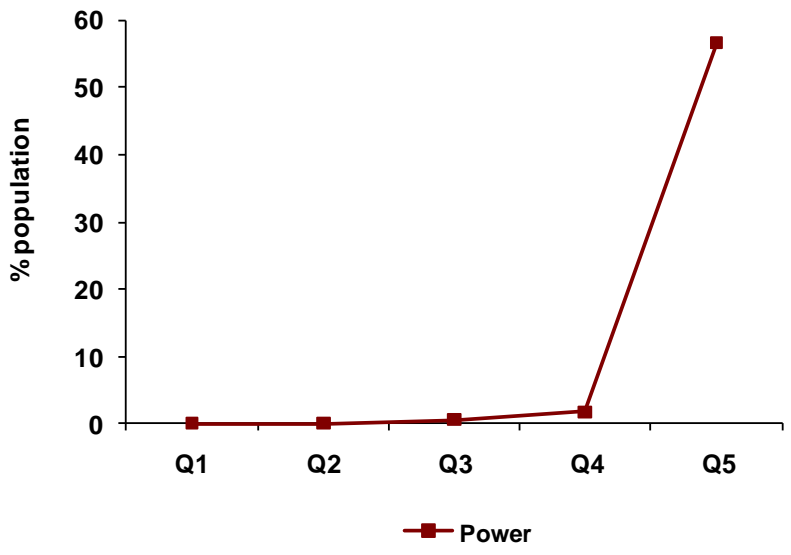

Source: Banerjee and others 2009.

Note: Q1-first budget quintile, Q2—second budget quintile, and so on. 
Given that access to piped water and electricity is granted to the top quintile of the income distribution, the subsidy policy is very regressive (figure 30). Estimates show that the distributional incidence of water subsidies is 0.02 and of electricity subsidies is 0.06 (below 1 is regressive, and closer to 0 is highly regressive).

Figure 30. Distributional incidence of water and power subsidies

a. Water

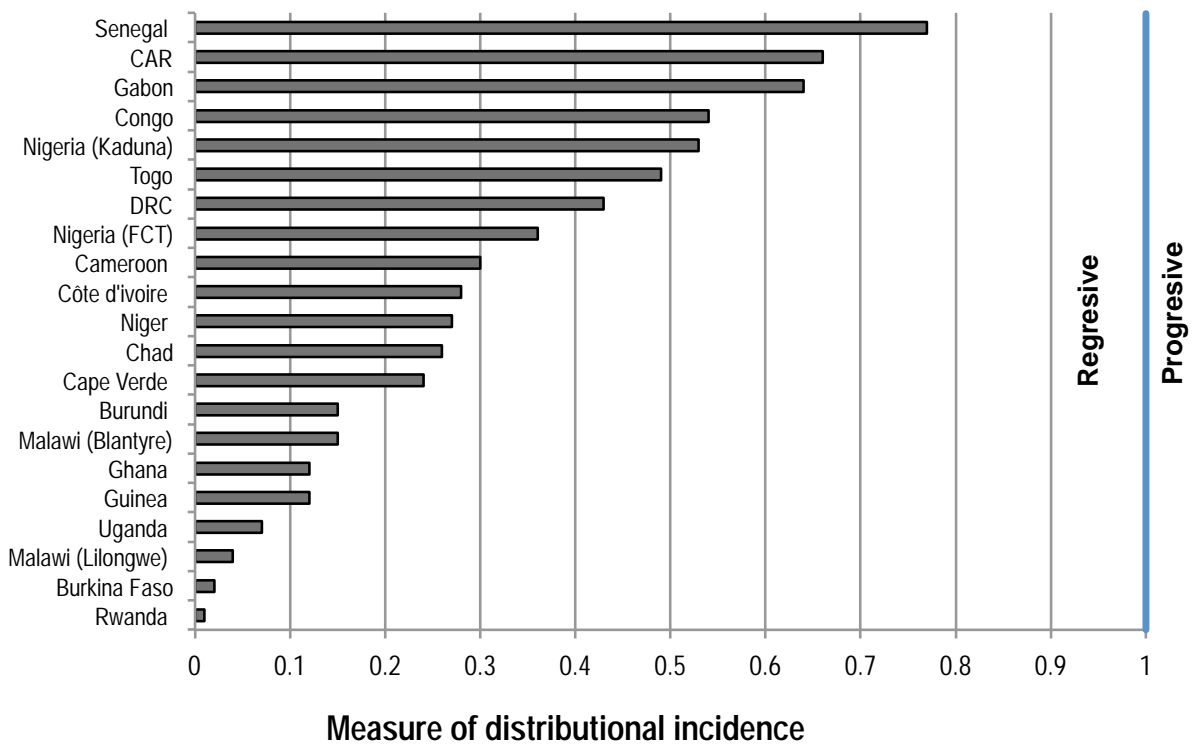

b. Power

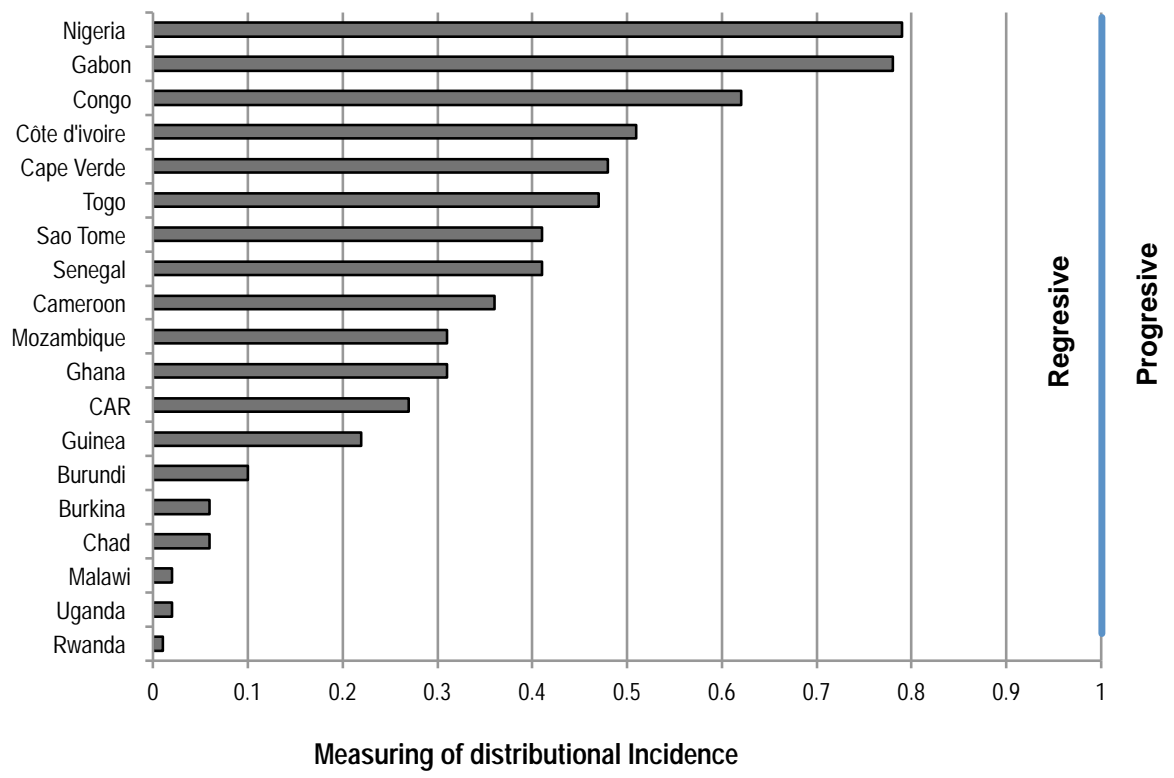

Source: Banerjee and others 2009.

Note: $\mathrm{CAR}=$ Central African Republic; DRC = Democratic Republic of Congo. 
How expensive would utility bills become if cost-reflective tariffs were applied? With a power costrecovery tariff of $\$ 35$ cents per $\mathrm{kWh}$ and a monthly subsistence consumption of $25 \mathrm{kWh}$-which is capable of meeting the most basic needs - the associated utility bill would come to $\$ 10$ per month. Based on the distribution of household budgets in Burkina Faso, monthly utility bills at these levels would be affordable by about 50 percent of the population (figure 31). Subsistence consumption of $4 \mathrm{~m}^{3}$ per month for water would cost $\$ 4.60$ and would be affordable for most of the population.

Figure 31. About half of households are able to afford subsistence consumption when the monthly bill is $\$ 10$

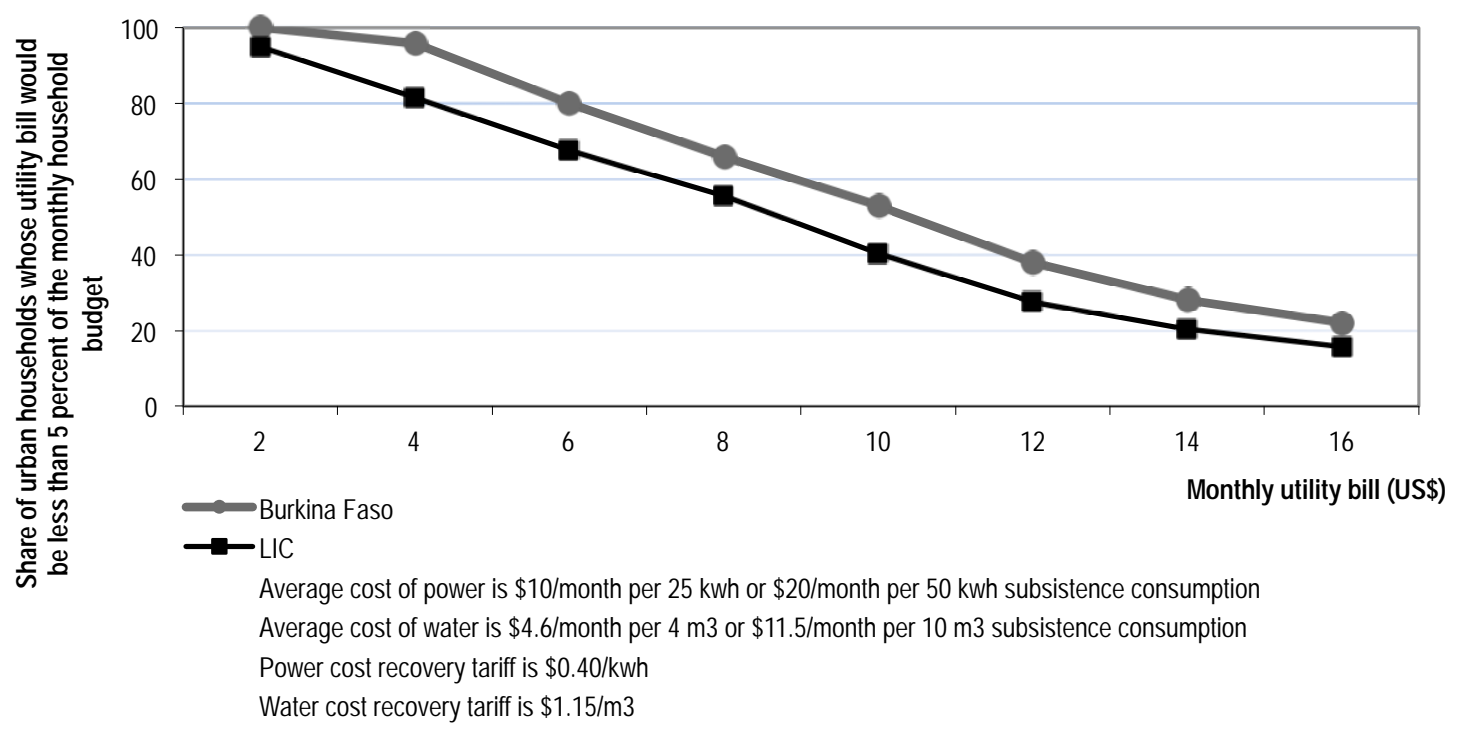

Source: Banerjee and others 2009

Note: $\mathrm{LIC}=$ low-income country; kWh = kilowatt-hour.

Undercollection of bills cost Burkina Faso \$16 million a year in power and a further \$1 million a year in water. Burkina Faso's power utility, SONABEL, is relatively less efficient than other utilities in neighboring countries and than its low-income peers (figure 32). It managed to collect 91 percent of its billings as of 2008. Distribution losses are high, at 16-17 percent-compared to the best practice benchmark of 10 percent-likely an indication of an overstretched transmission network. As a result, SONABEL's operational inefficiencies absorb 0.49 percent of GDP (figure 32a). In the case of the water sector, and in contrast to many other African countries, distributional losses are not a concern since they are at a level of nonrevenue water, at 18 percent, which is below the international benchmark of 20 percent of water production. ONEA's implicit collection ratio, at 98 percent of billings, is relatively high, and therefore the associated burden of 0.013 percent of GDP is lower than that of other LICs, which absorb 0.17 percent of their GDP (figure 32b). 
Figure 32. Undercollection and losses in the power and water sectors, as percentage of GDP

a. Power sector

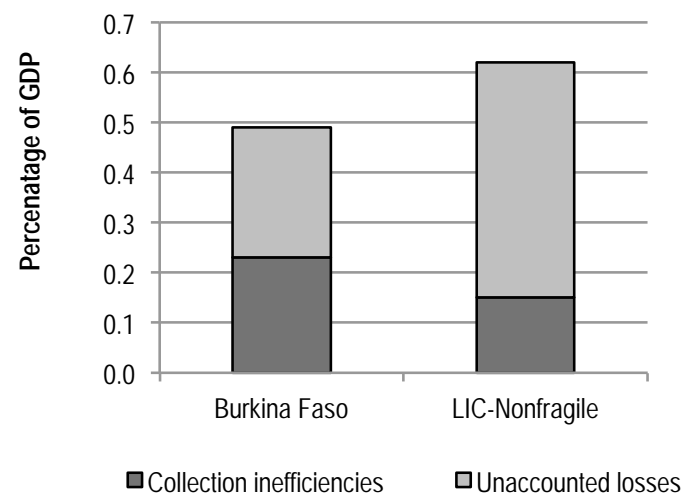

b. Water sector

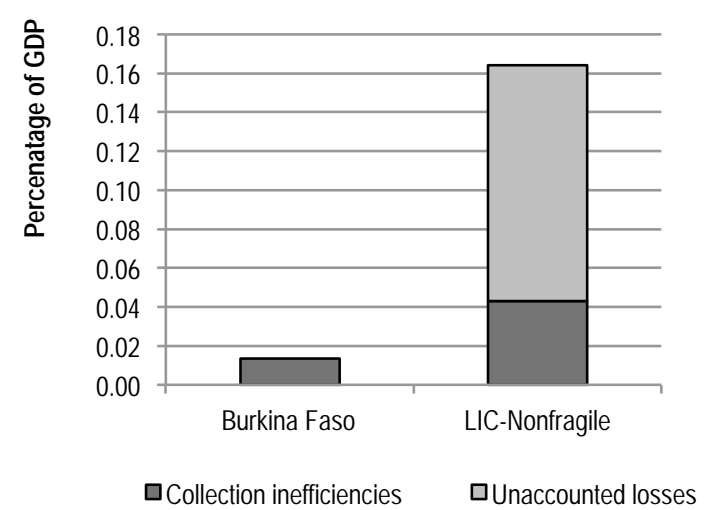

Source: Banerjee and others 2009.

\section{Annual funding gap}

Burkina Faso's infrastructure funding gap amounts to \$123 million per year, or about 4 percent of GDP. The biggest funding gap is found in the water supply and sanitation sector, where the shortfall is $\$ 85$ million; a \$44 million gap is found in the transport sector and \$35 million in the ICT sector (table 20). Additionally, if potential efficiency gains were fully captured in the power sector, it would benefit from a surplus of funds over identified needs of about $\$ 41$ million per year. This surplus could be used within the power sector, but also allocated toward covering the funding gap in other infrastructure sectors.

Table 20. Funding gaps by sector

$\$$ million per year

\begin{tabular}{lccccc}
\hline & ICT & Power & Transport & WSS & Total \\
\hline Needs & $(119)$ & $(142)$ & $(144)$ & $(208)$ & $(613)$ \\
\hline Spending & 83 & 103 & 81 & 119 & 387 \\
\hline Within sector reallocation & 0 & 0 & 20 & 0 & 20 \\
\hline Potential efficiency gains & 0 & 80 & 0 & 3 & 83 \\
\hline (GAP) or surplus & $\mathbf{( 3 5 )}$ & & $\mathbf{( 4 4 )}$ & $\mathbf{( 8 5 )}$ & $\mathbf{( 1 2 3 )}$ \\
\hline
\end{tabular}

Source: Derived from Foster and Briceño-Garmendia (2009).

Note: Potential overspending is not included in the calculation of the funding gap, because it cannot be assumed that it would be applied toward other infrastructure sectors.

WSS = water supply and sanitation; ICT = information and communication technology.

$-=$ Not available.

\section{What else can be done?}

The funding gap can be addressed only by raising additional finance or, alternatively, by adopting lowercost technologies or less-ambitious targets for infrastructure development.

Burkina Faso has the potential of raising additional finance from the private sector. Over the early 2000s, Burkina Faso captured private investment commitments worth around 1.2 percent of GDP in the ICT sector, comparing favorably with many of its peers (figure 33). On the other hand, many countries 
have done better, and some have attracted private investors not only in the ICT sector but also in the the transport and power sectors. Countries such as the Democratic Republic of Congo, Liberia, Nigeria, Uganda, Kenya, and Senegal have all captured private investment commitments between 1.8 and 2.5 percent of their GDP.

Figure 33. Burkina Faso needs to attract more private investment, especially outside the ICT sector

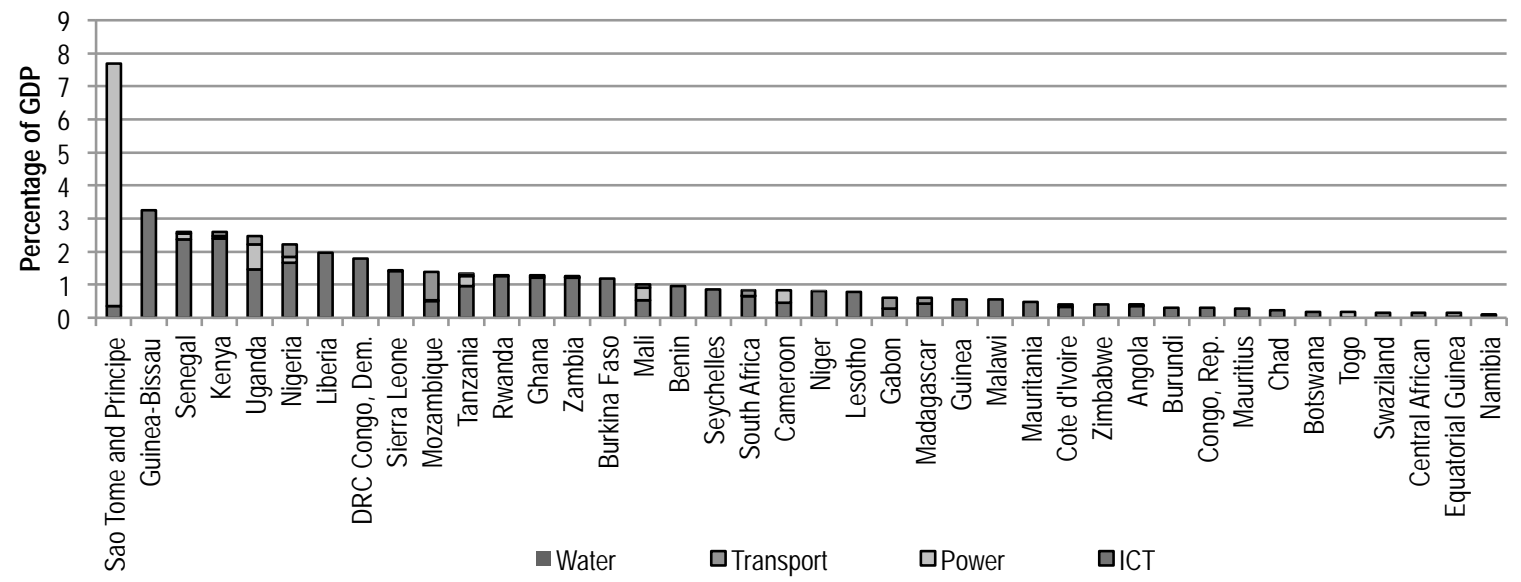

Source: AICD calculations

Note: ICT = information and communication technology; GDP = gross domestic product.

Adopting lower-cost technologies could substantially reduce the cost of meeting the posited infrastructure targets, and thus eliminate the funding gap. For example, meeting the MDGs for water supply and sanitation with lower-cost technologies than previously used (such as stand posts, boreholes, and improved latrines) could reduce the associated price tag from $\$ 208$ million to $\$ 165$ million each year. Similarly, meeting transport connectivity standards using lower-cost road surfacing technologies (such as single-surface treatment) could reduce the associated annual price tag from \$144 million to \$105 million. The overall savings from these measures would amount to $\$ 82$ million, which could eliminate the country's infrastructure funding gap, underscoring the importance of technology choices (table 21).

Table 21. Adopting alternate strategies to meet targets might represent important savings

\begin{tabular}{lcccccc} 
\$ million & Before & After innovation & Savings as \% of & \multicolumn{2}{c}{$\begin{array}{c}\text { Savings as \% of } \\
\text { sector funding } \\
\text { gap }\end{array}$} & $\begin{array}{c}\text { Sotal } \\
\text { funding gap }\end{array}$ \\
\hline Power trade & 142 & 142 & 0 & $0 \%$ & $0 \%$ & $72 \%$ \\
\hline WSS appropriate technology & 208 & 165 & 43 & $50 \%$ & $66 \%$ \\
\hline Roads appropriate technology & 144 & 105 & 39 & $89 \%$ & 6 \\
\hline
\end{tabular}

Source: AICD calculations

Note: WSS = water supply and sanitation.

If Burkina Faso had no means of raising additional finance for infrastructure, any additional way to meet the targets identified here would take a longer period of time than the decade contemplated at the outset of this exercise. If the country were to make efficiency gains while holding spending at current 
levels, it could meet the identified infrastructure targets in 16 years-that is, by 2024 . Without tackling inefficiencies, reaching these targets would require a much longer period. 


\section{Bibliography and references}

This country report draws upon a wide range of papers, databases, models, and maps that were created as part of the Africa Infrastructure Country Diagnostic. All of these can be downloaded from the project Web site: http://www.infrastructureafrica.org. For papers go to the document page (http://www.infrastructureafrica.org/aicd/documents), for databases to the data page (http://www.infrastructureafrica.org/aicd/tools/data), for models go to the models page (http://www.infrastructureafrica.org/aicd/tools/models), and for maps to the map page (http://www.infrastructureafrica.org/aicd/tools/maps). The references for the papers that were used to compile this country report are provided in the table below.

\section{General}

AICD (Africa Infrastructure Country Diagnostic). 2010a. “Africa's Infrastructure: A Time for Transformation.” Foster, Vivien, and Cecilia Briceño-Garmendia, eds. Paris and Washington, DC: Agence Française de Développement and World Bank. http://www.infrastructureafrica.org.

—_. 2010b. "ECOWAS's Infrastructure: A Regional Perspective." Africa Region, World Bank, Washington, DC.

World Bank. 2009a. Country Assistance Strategy for Burkina Faso FY10-12. Washington, DC: World Bank.

—. 2011. Doing Business 2011: Making a Difference for Entrepreneurs. Washington, DC.

\section{Financing}

Briceño-Garmendia, Cecilia, Karlis Smits, and Vivien Foster. 2009. "Financing Public Infrastructure in Sub-Saharan Africa: Patterns and Emerging Issues.” AICD Background Paper 15, Africa Region, World Bank, Washington, DC.

\section{Growth}

Calderón, César. 2009. "Infrastructure and Growth in Africa." Policy Research Working Paper 4914, World Bank, Washington, DC.

Escribano, Alvaro, J. Luis Guasch, and Jorge Pena. 2009. “Assessing the Impact of Infrastructure Quality on Firm Productivity in Africa." Policy Research Working Paper 5191, World Bank, Washington, DC.

Yepes, Tito, Justin Pierce, and Vivien Foster. 2009. "Making Sense of Africa's Infrastructure Endowment: A Benchmarking Approach.” Policy Research Working Paper 4912, World Bank, Washington, DC. 


\section{Information and communication technologies}

Ampah, Mavis, Daniel Camos, Cecilia Briceño-Garmendia, Michael Minges, Maria Shkaratan, and Mark Williams. 2009. "Information and Communications Technology in Sub-Saharan Africa: A Sector Review.” AICD Background Paper 10, Africa Region, World Bank, Washington, DC.

Mayer, Rebecca, Ken Figueredo, Mike Jensen, Tim Kelly, Richard Green, and Alvaro Federico Barra. 2009. "Connecting the Continent: Costing the Needs for Spending on ICT Infrastructure in Africa.” AICD Background Paper 3, Africa Region, World Bank, Washington, DC.

\section{Irrigation}

Svendsen, Mark, Mandy Ewing, and Siwa Msangi. 2008. "Watermarks: Indicators of Irrigation Sector Performance in Africa.” AICD Background Paper 4, Africa Region, World Bank, Washington, DC.

You, L., C. Ringler, G. Nelson, U. Wood-Sichra, R. Robertson, S. Wood, G. Zhe, T. Zhu, and Y. Sun. 2009. "Torrents and Trickles: Irrigation Spending Needs in Africa." AICD Background Paper 9, Africa Region, World Bank, Washington, DC.

\section{Power}

Briceño-Garmendia, Cecilia and Maria Shkaratan. 2010. "Power Tariffs: Caught between Cost Recovery and Affordability." First draft, February 2010.

Eberhard, Anton, Vivien Foster, Cecilia Briceño-Garmendia, Fatimata Ouedraogo, Daniel Camos, and Maria Shkaratan. 2008. "Underpowered: The State of the Power Sector in Sub-Saharan Africa." AICD Background Paper 6, Africa Region, World Bank, Washington, DC.

Foster, Vivien, and Jevgenijs Steinbuks. 2009. "Paying the Price for Unreliable Power Supplies: In-House Generation of Electricity by Firms in Africa." Policy Research Working Paper 4913, World Bank, Washington, DC.

Rosnes, Orvika, and Haakon Vennemo. 2009. "Powering Up: Costing Power Infrastructure Spending Needs in Sub-Saharan Africa.” AICD Background Paper 5, Africa Region, World Bank, Washington, DC.

World Bank. 2005. Project Concept Document on a Proposed IDA Credit in the Amount of US\$40.0 Million Equivalent to the Government of Burkina Faso and on a GEF Grant of about US\$3.0 Million for a Energy Access Project. December 29, 2005

\section{Transport}

Bofinger, Heinrich C. 2009. "An Unsteady Course: Growth and Challenges in Africa's Air Transport Industry.” AICD Background Paper 16, Africa Region, World Bank, Washington, DC.

Bullock, Richard. 2009. "Off Track: Sub-Saharan African Railways.” AICD Background Paper 17, Africa Region, World Bank, Washington, DC. 
Carruthers, Robin, Ranga Rajan Krishnamani, and Siobhan Murray. 2009. "Improving Connectivity: Investing in Transport Infrastructure in Sub-Saharan Africa." AICD Background Paper 7, Africa Region, World Bank, Washington, DC.

Gwilliam, Ken, Vivien Foster, Rodrigo Archondo-Callao, Cecilia Briceño-Garmendia, Alberto Nogales, and Kavita Sethi. 2008. "The Burden of Maintenance: Roads in Sub-Saharan Africa.” AICD Background Paper 14, Africa Region, World Bank, Washington, DC.

Kumar, Ajay, and Fanny Barrett. 2008. "Stuck in Traffic: Urban Transport in Africa.” AICD Background Paper 1, Africa Region, World Bank, Washington, DC.

Ocean Shipping Consultants, Inc. 2009. "Beyond the Bottlenecks: Ports in Africa." AICD Background Paper 8, Africa Region, World Bank, Washington, DC.

World Bank. 2007. Burkina Faso: The Challenge of Export Diversification for a Landlocked Country, Diagnostic Trade Integration Study for the Integrated Framework Program. Washington, DC: World Bank.

—_ 2009b. Burkina Faso: Promoting Growth, Competitiveness and Diversification. Country Economic Memorandum. Volume III: Enhancing Growth Factors. Report No. 51815-BF, Washington, DC, November 24.

World Bank/AfDB (African Development Bank). 2009. "Railway Concessions in Sub-Saharan Africa: Lessons Learned." Joint presentation. Washington, DC.

World Bank/Mott Mac Donald. 2009. Evaluation of the Proposed Ouagadougou-Donsin Airport Development, Burkina Faso. Washington, DC: World Bank.

\section{Water supply and sanitation}

Banerjee, Sudeshna, Vivien Foster, Yvonne Ying, Heather Skilling, and Quentin Wodon. 2009. "Cost Recovery, Equity, and Efficiency in Water Tariffs: Evidence from African Utilities." AICD Working Paper 7, Africa Region, World Bank, Washington, DC.

Banerjee, Sudeshna, Heather Skilling, Vivien Foster, Cecilia Briceño-Garmendia, Elvira Morella, and Tarik Chfadi. 2008. "Ebbing Water, Surging Deficits: Urban Water Supply in Sub-Saharan Africa.” AICD Background Paper 12, Africa Region, World Bank, Washington, DC.

Fall, Matar, Phillipe Marin, Alain Locussol, and Richard Verspyck. 2009. "Reforming Urban Water Utilities in Western and Central Africa: Experiences with Public-Private Partnerships." Water Sector Board Discussion Paper Series, PPIAF Paper No.13, World Bank, Washington DC.

Gulyani, Sumila, Debabrata Talukdar, and Darby Jack. 2009. "Poverty, Living Conditions, and Infrastructure Access: A Comparison of Slums in Dakar, Johannesburg, and Nairobi.” AICD Working Paper 10, Africa Region, World Bank, Washington, DC.

Keener, Sarah, Manuel Luengo, and Sudeshna Banerjee. 2009. "Provision of Water to the Poor in Africa: Experience with Water Stand posts and the Informal Water Sector." AICD Working Paper 13, World Bank, Washington, DC. 
Mwangi, Lawrence W. 2007. "Burkina Faso's Experience: Small-Scale Water Service Providers." Presentation by chief executive officer of Athi Water Services Board to the PPIAF Annual Meeting, May 23-24. Washington, DC.

Morella, Elvira, Vivien Foster, and Sudeshna Ghosh Banerjee. 2008. "Climbing the Ladder: The State of Sanitation in Sub-Saharan Africa.” AICD Background Paper 13, Africa Region, World Bank, Washington, DC.

WSP (Water and Sanitation Programme). 2010. Water Supply and Sanitation in Burkina Faso: Turning Finance into Services for 2015 and Beyond. An AMCOW Country Status Overview. Washington, DC: World Bank.

WHO (World Health Organization) Joint Monitoring Programme (JMP). 2010. "Burkina Faso Estimates for the use of Improved Drinking-Water Sources." http://www.wssinfo.org/resources/documents.html.

— 2010b. "Burkina Faso Estimates for the Use of Improved Sanitation Facilities." http://www.wssinfo.org/resources/documents.html. 